\title{
"You give me letters instead of money?" Commercial transactions in the Near East and the Western Mediterranean ca. 1100-600 BCE: social innovation and institutional inhibition of Phoenician commerce
}

\author{
Eleftheria Pappa*
}

\begin{abstract}
PAPPA, E. "You give me letters instead of money?" Commercial transactions in the Near East and the Western Mediterranean ca. 1100-600 BCE: social innovation and institutional inhibition of Phoenician commerce. R. Museu Arq. Etn., 28: 1-30, 2017.
\end{abstract}

\begin{abstract}
Two of the most crucial and fundamental problems in proto-historical and anthropological research relate to the popularization of literacy and the origins of money. The reasons behind the sudden and sweeping spread of the Phoenician alphabet in the $8^{\text {th }}-7^{\text {th }} \mathrm{c}$. BCE remain unresolved, yet endlessly debated. At the same time, the scholarship paradox that the Phoenicians, the traders of antiquity par excellence, seemingly did not use any form of physical currency remains largely overlooked, despite their Mediterranean-wide commercial networks. Yet recent research points to the high degree of the monetization of Phoenician commercial networks, as well as to the fact that forms of 'proto-currency' were circulating in the Levant at least from the $8^{\text {th }} \mathrm{c}$. BCE. This article aims to look at these two problems from an entirely novel perspective, exploring the links between them and testing whether causality can be established between the sudden popularization of literacy and the absence of currency in the Phoenician economy, focusing on the Western Mediterranean. It suggests that increasing monetization developed through patterns of commercial exchanges established in the Near East during the $3^{\text {rd }}$ millennium BCE, which allowed for transactions using promissory notes, with payments made in various means, for example via an established index of value (e.g. to silver).
\end{abstract}

Keywords: Monetization; Literacy; Alphabet; Phoenicians; Western Mediterranean.

\section{Introduction}

$\mathrm{T}$ wo of the most crucial and fundamental problems in archaeological and historical research relate to the popularization of literacy and the origins of money. These two

* Museu de Arqueologia e Etnologia da Universidade de São Paulo. Doctor of Philosophy at Oxford University. <eleftheria_pappa@usp.br> issues have remained for decades at the forefront of scholarly attention in many fields (ancient and economic history, social anthropology, archaeology) - but separately. The reasons behind the sudden and sweeping spread of the Phoenician alphabet in the $9^{\text {th }}-7^{\text {th }} \mathrm{c}$. BC in the Mediterranean in previously illiterate communities remain unresolved yet endlessly debated. Concurrently, it remains an overlooked in the scholarship paradox that the Phoenicians, 
"You give me letters instead of money?" Commercial transactions in the Near East and the Western Mediterranean ca. 1100-600 BCE: social innovation and institutional inhibition of Phoenician commerce.

R. Museu Arq. Etn., 28: 1-30, 2017.

the traders of antiquity par excellence, did not make use of a currency, despite their Mediterranean-wide commercial networks ${ }^{1}$. Yet recent research points to the high degree of the monetization of the Phoenician economy at least from the $8^{\text {th }} \mathrm{c}$. BC. The approach here is to look at these two crucial areas of research (popularization of literacy, origins of money) from a novel perspective, examining them in tandem.

In the present paper, they are brought together, looking not for individual reasons that can be used as explanatory factors separately, but instead for the institutional mechanisms and socio-economic frameworks(s) that precipitated their development. The links between them will be explored, testing whether causality can be established between the sudden popularization of literacy and the absence of currency in the Phoenician economy, which affected areas across the European and African shores of the Mediterranean. The historical process of Phoenician expansion provides the context into which the spread of alphabetic literacy and the paradox of a monetized but currencyless Phoenician economy can be both causally examined. The article proposes to move the debate on the spread of the alphabet from mechanistic explanations (the 'circulation' of alphabetic scripts through trade) to focusing it instead on the exact social and economic mechanisms of this process. It focuses on the 'far western' Mediterranean in juxtaposition with the Near East, outlining the argument, evidence and their discussion.

The Phoenician colonization in the Mediterranean during the early first millennium $\mathrm{BC}$ led to the spread from the Near East to the Atlantic of a civilization and forms of socio-economic organization, and ideological and religious thought that were previously unattested (Pappa 2013, 2015a). Commodities travelled with people, and

1 The only similar observation comes in fact from outside the field of Phoenician studies, see Florenzano (2004: 70) and Scheidel (2010: 285): "The Phoenician and Carthaginian experience shows that there is nothing inevitable about coinage [...]. Coins are inherently not irresistible.". along with them, ways of organizing society, of developing the economy and technology, both material and immaterial. Among the latter was script, which in the western part of Europe first appeared in Iberia, with the arrival of the Phoenicians (Fig. 1). The spread of the Phoenician alphabet subsequently gave rise to local forms of writing.

The expansion in the Mediterranean of market-based commercial networks by the Phoenicians $\left(9^{\text {th }}-6^{\text {th }}\right.$ c. BC) is archaeologically attested, documenting multiple trade routes and partners, mass production of commodities, and the carving of 'niche markets'. These elements attest to market-based commerce, whose growth reveals the increasing monetization of Phoenician economy, showing that the concept of 'money' as a store of wealth and index of value existed among the Phoenicians. It is not known what physical form money may have attained as a direct means of payment given the apparent lack of a Phoenician currency. Only belatedly in the $5^{\text {th }} \mathrm{c}$. BC was coinage introduced in Phoenicia under Persian influence.

Curiously, this lack of currency coincides with the expansion of Phoenician mercantile networks in the Mediterranean, which could seemingly have benefited from the use of a currency for transactions. Even more problematically, types of silver-based currency existed in the contemporary Near Eastern societies with which the Phoenicians maintained trading contacts. Yet for reasons unknown to us, they refrained from adopting something similar, implying that whichever system they used for transactions was considered efficient enough or presented other advantages (e.g. flexibility). In parallel, no hypothesis exists as to why writing became popular (spreading outside nonprofessional scribes) suddenly in the 8th c. BCE, i.e. nearly 1000 years after the alphabetic script had been invented. Neither is there a persuasive explanation for how this 'transmission' to the illiterate by that stage south European people occurred so rapidly. What prompted then its sudden and sweeping spread by the Phoenicians and could there be a relationship between it and the paradoxical suppression of currency-use in their market-based Phoenician economy? 


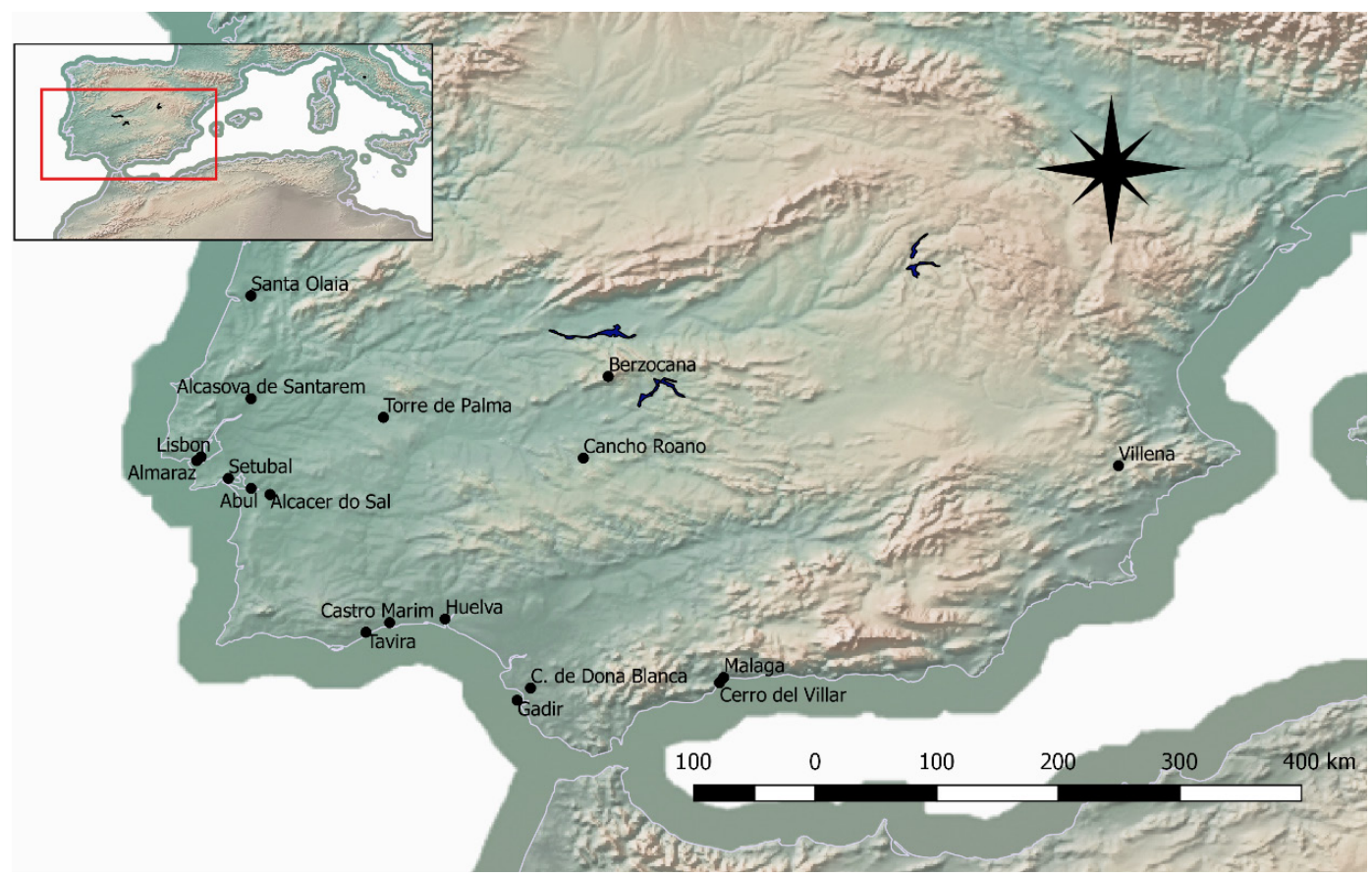

Fig. 1. Map of the Iberian Peninsula with sites mentioned in text.

Source: Author's elaboration.

The historical process of Phoenician commercial expansion provides the context into which these two crucial problems of research can be examined in relation to one another. Setting out to answer this question, a novel approach is adopted that examines both these fundamental yet highly problematic areas of research as interrelated aspects of the same phenomenon.

Looking at the spread of the alphabet in the Mediterranean from the function that literacy played within the Phoenician economy involves determining how Phoenician market-based commerce transactions were conducted, and whether literacy played any role therein. This examination has the potential of changing current views on two important problems: (1) the sudden popularisation of literacy (ca. 850-700 BCE) (2) the increasing monetisation of the Phoenician economy despite the (seeming) absence of currency. The innovation lies in examining the potential causality between forms of currency and literacy in areas of Phoenician commerce, seeking the institutional role that literacy played within commercial transactions. Such a study aims to open a dialogue with scholarship on Near Eastern cuneiform archives and economic history, which so far stands behind a watershed for Mediterranean archaeologists due to artificial academic boundaries.

The investigation will test the following hypothesis: a type of market-based commerce using phenomenally barter trade but actually employing written records of transactions, based on shared measures of value established in metal weight, offers an explanation for the overseas Phoenician monetary practices. Accordingly, the functional role that writing played within the Phoenician commercial system would explain both the swift spread of literacy in Mediterranean regions touched by Phoenician commercial networks and the absence of a physical form of Phenician currency. The key objective is to investigate if there is a relationship between the sudden and sweeping spread of the Phoenician alphabet and the paradoxical absence of currency use in 
"You give me letters instead of money?" Commercial transactions in the Near East and the Western Mediterranean ca. 1100-600 BCE: social innovation and institutional inhibition of Phoenician commerce.

R. Museu Arq. Etn., 28: 1-30, 2017.

the Phoenician economy. The sub-objectives relate to:

a. determining the way the Phoenician commerce operated in the Mediterranean without the use of currency as a means of payment and explore the role of institutions that made that possible

b. understanding whether Phoenician commercial mechanisms with Near Eastern polities that had already developed monetary uses of metal differed from those employed with societies in the Mediterranean

c. examining the way the mechanisms of Phoenician economy corresponded or interacted with neighbouring economies (neo-Assyrian), in terms of inflation, for example, recorded in contemporary Neo-Assyrian texts.

d. examining the potentially fundamental role literacy played within this system, by allowing transactions to be carried out using written records of which kinds of commodities were exchanged for other kinds of commodities according to shared measures of value established in metal weight.

In archaeology, the importance is placed on the degree of likelihood, so it is possible that the central hypothesis may not be corroborated or verified beyond any doubt. There is enough evidence to suggest that the popularisation of literacy functioned as a suppression factor for the introduction of a physical form of currency in the Phoenician economy, offering us a picture on interregional mechanisms of exchanges and the ways literacy spread that departs from the currently established way of tracing the spread of the alphabet in elite circles of international trade, through customs such as the Levantine marzeah and the Greek symposion.

The following sections examine the state of the art for early money origins, as well as for literacy, and then move on to framing the model and testing it on the basis of the archaeological evidence. The final synthesis brings together the different lines of investigation, detailing present limitations and future research possibilities.

\section{The popularization of literacy and monetization: problems and state of the art}

The $9^{\text {th }}-7^{\text {th }}$ c. BCE in the Mediterranean is a very dynamic period, characterized by many groundbreaking developments: regular, long-distance, deep-sea travel that led to inter-cultural connectivity through migration and commerce, widespread use of the iron and the spread of the Phoenician alphabet. The Phoenicians are often credited with the spread of the alphabet through their commercial networks, stretching from their city-states in Phoenicia to Cyprus, Malta, Sicily, north Africa and Iberia, including the Atlantic coasts of Portugal and Morocco. In this context, the ethnonym 'Phoenician' is used as an umbrella term referring to the inhabitants of not only Phoenicia proper (the territory south of Syria and north of the Akko plain), but also north Syrians and Aramaeans (Gubel 2006). Regardless of whether one uses the term 'diaspora', 'colonization' or 'expansion' to refer to this phenomenon, recent research from across the Mediterranean confirms the intense nature of this commercial process, with the discovery of a great concentration of Phoenician trading posts, outposts and settlements across the central and western Mediterranean littoral. These events were precipitated by socio-political changes in the Near Eastern homeland, including the emerging preeminence of the Phoenician city-states in the 'international scene' of the Early Iron Age Mediterranean. Yet their selfrule remained volatile, a fact often emphasized as a factor contributing in driving the Phoenician expansion westwards.

Traditionally, Early Iron Age Mediterranean scholarship has always drawn a link between this dynamic expansion of Phoenician commercial networks and the spread of the alphabet to European populations. Yet without an interdisciplinary focus and methodology that will utilize all extant documentation, hypotheses and explanations will remain one-sided and speculative. The same is true of the theorizing concerning the mechanisms of commercial transactions involved in this process. To an 
extent this is the symptom of a huge increase in the volume of excavations in Phoenicianperiod western Mediterranean, which have tended to take a regional perspective due to the sheer volume of evidence and linguistic barriers in the scholarship. With few exceptions (e.g. Kormikiari 2004; Sherratt \& Sherratt 1993; Sommer 2007), there have been no attempts to provide a new model of Mediterraneanwide Phoenician commerce departing from Frankenstein's (1979) seminal work of over three decades ago.

In the tradition of scholarship, writing has been considered a corollary to counting, especially in the bureaucratic Late Bronze Age palace societies of Egypt, Mesopotamia but also of the Aegean (Baker 2003; Michailidou 2005). It follows that script is considered to have been invented within the context of bureaucracy (Michailidou 2001: 53). However, as Schaps has noted, it is often that "people speak of the effects of the innovation as if the innovation itself made possible the behavior that it came to characterize" (Schaps 2004: 8). We should be cautious of this kind of teleological thinking that Michailidou (2001: 53) also acknowledges, stating that there are various stages of both counting and writing, which includes nonbureaucratic pursuits. The alphabet, in fact, if Goldwasser's (2001) refinement of an earlier hypothesis is correct, was invented in a polar opposite situational context, by Canaanite or other Semitic group slave miners in Egypt. However, it is the development of the original invention, the standardization of writing into a widely acceptable script, along with the standardization of metrical weights and their inclusion into a metrical system, which are made possible by a centralized authority (Michailidou 2001: 54). The balance weights themselves were invented within the context of needing to weigh metal in general, leading Michailidou (2001: 55) to postulate the connection of writing and counting as being embodied in the inscribed Egyptian and Near Eastern balance weights, referring to the value of weight, or giving information on proprietorship, king's reign or mentioning the name of a deity.
The monetarized, market-based Phoenician economy and the apparent absence of currency use

\section{Nature of the problem}

The archaeological record of the Phoenician expansion shows multiple trade routes, partners and diversification in commodities that reinforce the idea of market-based commerce. The growth of market-based Phoenician economy reveals its increasing monetarization, but on present knowledge, it remained free of currency until externally motivated to introduce coinage in the $5^{\text {th }} \mathrm{c}$. BCE. This is notably late by comparison to neighbouring regions, including western Asia Minor and the Aegean. Several studies have documented the existence of market mechanisms in the way Phoenician commerce was conducted, both from a wide-Mediterranean perspective (Aubet 2008; Frankenstein 1979; Pappa 2013; Sherratt \& Sherratt 1993) and looked at from a regional angle (e.g. Vives-Ferrándiz Sánchez 2005). The pertinent question of how a monetized economy functioned without a form of currency cannot be approached indirectly on the present state of knowledge. Clearly the concept of 'money' as a store of wealth and index of value existed in the Phoenician economy, but there are no hypotheses concerning the (physical) form that money may have attained as a store of wealth, index of value and direct means of payment given the apparent or real lack of a currency.

This problematic issue attains greater proportions when one considers that types of monetary currency existed in contemporary Near East, including in societies with which the Phoenicians maintained trading contacts. This clearly implies that the Phoenicians were acquainted with the concept. Yet seemingly for reasons unknown to us, they refrained from adopting a similar, archaeologically visible type of currency, implying that whichever system was in use in the Phoenician economy was considered efficient enough or presented other advantages (e.g. flexibility). Even more curiously, this coincided with the time the Phoenicians were expanding their mercantile 
"You give me letters instead of money?" Commercial transactions in the Near East and the Western Mediterranean ca. 1100-600 BCE: social innovation and institutional inhibition of Phoenician commerce.

R. Museu Arq. Etn., 28: 1-30, 2017.

networks in the Mediterranean, which at a first glance could have benefited from the use of a currency for transactions.

\section{Commercial exchanges and types of transactions in the ancient Near East}

In an anthropological study on money, finance and anthropology's currently established pursuits, Hart \& Ortiz (2014: $471,474)$ question received wisdoms on what exactly constitutes money, challenging not only academic division of labour but also "analytical categories, conceptual assumptions, and normative propositions", asking "Is money an object or an idea, real or virtual? One thing or many? Historically specific or a human universal? Is it a creature of markets or states, or both? Is it credit or debt, or both? Is money impersonal or personal, or both? If it is what it does, which function is most important medium of exchange, means of payment, unit of account, or store of wealth?".

Commencing with a strict definition of money is a hindrance to the historical research, too, on the origins of money and exchanges in general, since in attempting to discover the origins of a concept or innovation, a strictly delimited term for the concept would be "misleading" (Schaps 2004: 3). In the Greek and Roman world, several items were used as notional units of counting, be it in collective imagination or actual practice, such as cattle from the Homeric poems (where the ox is used as an index of value, but never a means of payment) to historical Rome (where the Latin word for 'cattle', pecunia, meant also 'money') (Schaps 2004: 9-10). While a physical form of money, in the sense we understand it nowadays, may have been independently invented in the Lydian world, the Plains of China and perhaps India, the introduction of coinage was the culmination of a process of millennialong monetized Near Eastern economies (Schaps 2004: 16).

Money use preceded coinage use in the ancient Near East, so that the monetary aspects of the economy can be seen in pre-coinage forms that were used as currency. Metal by weight (multiples/fractions of standardised weights) as a store and/or index of value and sometimes as direct means of payment was used (Balmuth 1975; Dercksner 1999; Kim 2001). In the Mesopotamian ration system, barley, wool, textiles and metals were used for payments (Breniquet 2013). Metal by weight (multiples/ fractions of standard weights) as a measure of value and sometimes as direct means of payment was used instead from the $3^{\text {rd }}$ millennium $B C$ in Mesopotamia. The issue regarding the circulation of silver by the mid- $3^{\text {rd }}$ millennium BCE in the Near East is not satisfactorily understood. It was used as an index of value and "means of equivalence", concurrently with wool in inland Syria and barley in Mesopotamia; in the latter region, silver was not native but had to be imported from lead ores in Anatolia and the Iranian plateau. Overall, it appears that it was not widely circulated as means of payment (Peyronel 2010: 929-930).

At least from the late $2^{\text {nd }}$ millennium $B C E$, metal by weight was used as a form of payment in the Levant. This function of metal fulfills some of the elements that define currency: pre-determined value and means of exchange. The other is the guarantee of authority, yet to be introduced. The progression towards a true currency is made when the guarantee of issuing authority is added to the pre-weighted metal, seen in some early $1^{\text {st }}$ millennium BCE hoards from the Levant (Gitin \& Golani 2004; Thompson 2003). From Cisjordan are known such $8^{\text {th }} \mathrm{c}$. BCE hoards, with ingots, fragmented jewellery and scrap metal, wrapped in cloth and bullae (clay seals) affixed on them as a guarantee of value or verification by an administrative authority (Gitin \& Golani 2004; Thompson 2003). Accordingly, such hoards attest to the monetary uses of silver bullion, pre-weighted ingots or 'rolled tongues' bars, fragmented jewellery and other scrap metal, documenting that diverse forms of proto-currency, mainly silver, although gold and its alloys, were circulating in the Near East, Anatolia and Cyprus in the form of pre-weighted metal and fractions of standard weights (Gitin \& Golani 2004; Thompson 2003). 
Overall, for three millennia, metal (silver, gold, or other precious metals) by weight was in use for payments in the Near East, though it remains an open question as to how widespread this was used as a means of direct payment, i.e. passing from hand to hand in transactions) (Peyronel 2010: 926-927)

By the mid-1st millennium BCE, developments in the Aegean revolutionized commerce in the Greek work and its colonial networks. The advent of coinage developed in Lydia out of the weighted-out metal that had been used in Anatolia and the Near East. Kroll (2011) proposed that its advent was born out of the need to regulate the value of the electron (natural alloy of gold and silver, collected from the Pactolus River), which naturally varied in the proportion of gold and silver. By officially stamping the metal in the form of pre-weighted ingots, the value became the one issued and guaranteed by the authority (Lydian King) rather than the outcome of the variable quantities of silver and gold naturally occurring in the alloy. From there, it spread to Greece quickly and to the Greek colonies in the Mediterranean and the Black Sea. In Etruria, up until the early $1^{\text {st }}$ millennium BCE, aspects of monetization are seen in the circulating fragmented ingots (aes rude) that were infrequently used rarely, silver bars, plates or strips, which have been found at sanctuaries and tombs and which probably had monetary value (Domínguez Arranz 2011). By the middle of the millennium, the Aegean and the central Mediterranean, monetization is seen in the mints that emerged in the Greek poleis of the colonial world and its neighbours. The Phoenician colonial network, nevertheless, remains visibly unaffected.

The $1^{\text {st }}$ millennium BCE was a time when the trading relations between Phoenicians and polities in Palestine/Israel are textually and archaeologically documented (Master 2003) and corresponds with the evidence for the standardization of Phoenician balance weights in a metric system that was compatible with the Egyptian and Babylonian ones. Phoenician weights have been found from Greece (Lefkandi) to Spain, e.g. in Huelva (Kroll 2011). In the Phoenician economy, however, the weighted metal does not appear to have functioned as currency (the metal itself was not exchanged but it only provided a standardized measure of shared value). It remains unknown whether the Phoenicians occasionally used proto-currencies when trading with other Near Easterners.

At this time, commercial exchanges between Phoenicians and Palestine are textually and archaeologically documented. At this time, the Phoenicians still lacked a (proto-) currency. However, there is a standardization of Phoenician balance weights in a metric system compatible with the Egyptian and Babylonian ones (Kroll 2011). Diverse systems of convertibility in the weight systems were used in the Near East and the eastern Mediterranean from the Bronze Age with diverse mathematical formulas tested by the palaces or other central authorities. It is this centrally-established convertibility that explains the longevity of their usage (Alberti, Ascalone \& Peyronel 2006: 1-3; Mederos \& Lamberg-Karlovsky 2004). Such a process indicates an interest in creating norms of commercial exchanges on an interregional level. In the western Mediterranean, traces of the early weight systems used by the Phoenicians are detectable in the first coins minted in Iberia in later centuries, with reference to the ancient Phoenician metrology (García-Bellido 2011).

\section{Commercial exchanges and types of transactions in the Phoenician economy}

In the Phoenician economy, metal itself does not appear to have been exchanged itself in commercial transactions as a means of payment. It could have, however, provided a standardized index of value. There has been little attention paid to the implications of this simple fact: such a form of payment would require written accounts of transactions, specifying which kinds of commodities were exchanged for other kinds of commodities according to shared measures of value established in metal weight, e.g. with reference to silver weight.

That such written accounts have not survived, unlike the Neo-Assyrian or 
"You give me letters instead of money?" Commercial transactions in the Near East and the Western Mediterranean ca. 1100-600 BCE: social innovation and institutional inhibition of Phoenician commerce.

R. Museu Arq. Etn., 28: 1-30, 2017.

Neo-Babylonian transaction records, would have been the result of record-keeping on perishable materials (a medium used such as papyrus, parchment) but not clay tablets, which survived in the archaeological record when accidentally fired (e.g. during the destruction of cities by fire). By contrast, Near Eastern official records of payments ( $3^{\text {rd }}-1^{\text {st }}$ millennia BC) have survived (e.g. Charpin 2010). A book-keeping system of payments is documented in the Neo-Babylonian cuneiform archives $\left(6^{\text {th }} \mathrm{c}\right.$. BCE) that record money-lending and tax-incurring transactions in the institutional and private sectors (Jursa 2010: 469-475). They attest to a sophisticated silver-money-based economy, which often lacked an immediate physical form of currency as a means of payment. Securities (in writing) and promissory notes in cuneiform tablets were used for transactions and silver as a store of wealth (Baker 2003: 255-256). By the $6^{\text {th }} \mathrm{c}$. BC, record-keeping accounts and private letters in cuneiform suggest that silver was being used as a means of payment, along with other means of payment (barley, wool, base metals) and barter exchange (Jursa 2010: 772-773; Jursa 2015). If it were not for the written Babylonian clay tablet records, we would not have known of the complexity of the economy, to the degree that there is talk of "market performance" even (van der Spek, van Leeuwen \& van Zanden 2015).

A reappraisal of older data can potentially revolutionize our understanding of Phoenician commercial mechanisms. New interpretations include the potentially monetary uses of silver found in the $7^{\text {th }} \mathrm{c}$. BCE Hacksilber hoard at Tell Keisan, a Palestinian site with Phoenician affinities and in $9^{\text {th }}-7^{\text {th }} \mathrm{c}$. BCE hoards found in the Aegean traditionally attributed to 'Near Eastern craftsmen', e.g. the $9^{\text {th }}$ c. BCE Khaniale Tekke Tomb in Crete (Thompson 2003: 91-92). The discovery of iron spits at the Phoenician site of Mogador, Morocco may also be relevant to this discussion. Yet there is a wide geographical distance between the two sets of evidence, as well as a level of disjunction between the postulated type of currency attested. This necessitates a fresh view, with less of the parochialism and myopia of entrenched disciplinary divisionary mind-sets, which aims to examine all available datasets for the absence or not of currency in the Phoenician commercial systems, which is currently lacking.

The origins of alphabet and the popularization of literacy

\section{The popularization of literacy: nature of the problem}

For the first time in the $8^{\text {th }} \mathrm{c}$. BCE, the knowledge of writing shifts from being the prerogative of a professionally trained class of scribes, to becoming a popular skill. This revolutionizes not merely the ability and methods of communication but also cognition (Sanders 2004: 37). It is a common acceptance that during the late $9^{\text {th }} \mathrm{c}$. BCE, Greeks adopted the script by the Phoenicians. By the late $8^{\text {th }}$ c. BCE, Greek-speaking people stretching from Macedonia to central Italy were already composing complex poetic verses in tetrachaic metre in their regional Greek dialects and alphabets, inscribing them on vases during sympotic parties in what appears to have been impromptu actions (e.g. Tzifopoulos 2012). The Homeric poems were written soon after the introduction of the alphabet (e.g. Powell 1991). These activities reflect a casual use of the script, evincing both familiarity and competence. How did such a swift process of the alphabetic spread occur then? And what was the role of commerce?

The current view in the scholarship concerning the adoption and adaptation of the alphabetic script is that it occurred at trading posts in the Near East or in the Aegean Sea, where Phoenicians came into contact with people of other ethnic origins. Greeks, for example, are thought to have adopted the alphabet via trading posts such as Al Mina in Syria. In his seminal work the 'Great Sea', Abulafia (2011: 92-93) suggested that the Etruscans adopted their alphabet from Chalcidian Greeks settled at Pithekoussai, thus explaining why the letter forms of the Latin alphabet (derived from the Etruscan) are different from the Greek 
letter-phonemes combinations, as known from the Attic alphabet that subsequently became dominant in the Greek world. A $7^{\text {th }}$ c. BCE pinax from Marciliana d' Agua (Grosseto) in Etruria recording the Greek alphabet in boustrophedon, probably an abecedary, supports this view. Occasionally different alphabets are found in parallel, such as in the royal dedication of the Etruscan-Phoenician golden tablets at the temple of Pyrgi Santa Severa) in Etruria (Abulafia 2011: 97).

Such findings are used to support the view that areas where commerce took place brought people of different cultures together and 'somehow' the alphabet was transmitted and adapted. There are only speculations regarding the exact mechanisms of this 'transmission'. Trading posts are seen as the settings where social institutions such as the Greek symposion (elite male drinking party) favoured knowledge transfer, through the development of close social and inter-cultural ties. Others place emphasis on inter-cultural familial relationships, whereby for example, the bilingual offspring of a Greek-Etruscan conjugal relationship could be credited with the first local adaptation of the Greek alphabet for the Etruscan language, based on the bilingualism that their mixed heritage conferred. Generally, the explanations remain mostly conjectural. Such theories can never be refuted or verified, since the archaeological record of the Early Iron Age Mediterranean is insufficient for that. These hypotheses are, in other words, conjectural. They are based on the 'single stroke of genius' explanation, according to which an individual developed a remarkably innovative idea, with a sweeping social impact. Such hypotheses are not just impossible to document historically or archaeologically - they are also less convincing in that they do not offer an explanation for the persistence and dissemination of this innovation, be that the adoption or the adaptation of the alphabetic script. It has to be emphasized that this swift adoption of the alphabet occurred in societies that were completely illiterate at that stage, such as mainland Greeks (who had been illiterate for centuries following the disappearance of the Bronze Age Linear scripts) or the populations of South-Western Iberia. In the latter case, the adoption of the Phoenician alphabet resulted in its partial adaptation into a syllabary (Valério 2008). The adaptation of an alphabetic script into a syllabic one in itself demonstrates that the alleged innate superiority of the alphabet as a reason for its spread is not convincing at all and does not stand to the scrutiny of the evidence.

\section{The origins of the alphabet and its sudden popularization a millennium later}

New archaeological and epigraphic research has radically altered our knowledge regarding the origins of the alphabet, conventionally referred to as 'Phoenician'. Recent research dates its invention to a much earlier, than previously thought, period, at the beginning/middle of the $2^{\text {nd }}$ millennium, ca. 1700 or even earlier (Lemaire 2008). No single hypothesis exists as to the circumstances that led to this invention. Although the protoalphabet was most likely invented for the Canaanite language in the $2^{\text {nd }}$ millennium BCE (Goldwasser 2011; Lemaire 2008), the resultant script, made of characters representing individual consonantal values was attested sparsely in the next 700 years, used mainly for graffiti and simple dedications ${ }^{2}$.

By contrast, the formal languages of correspondence of the Late Bronze Age Canaanite city-states remained the elite and foreign languages of the time (e.g. Akkadian)

2 Most likely, this took place in Egypt, under the court of the Hyksos dynasty of rulers (of Semitic origin), whose dominance extended from south Palestine to the Egyptian Delta or alternatively, in the Sinai desert, where 45 inscriptions have been found, considered to be alphabetic. Regarding the latter possibility, it was suggested that the visibility and ubiquity of the Egyptian pharaonic hieroglyphic inscriptions gave the inspiration to the Canaanite miners of the turquoise mines of Serabit el-Khadim (in the Sinai) to develop a writing system of their own. The alphabet was derived by means of acrophony from the Egyptian images of hieroglyphs, but most likely without any phonological or semantic input from the Egyptian language and script: simply put, the hieroglyphs provided the idea to the illiterate miners, who could not read the hieroglyphs, to develop a writing system of their own for the Canaanite language (Goldwasser 2011). 
"You give me letters instead of money?" Commercial transactions in the Near East and the Western Mediterranean ca. 1100-600 BCE: social innovation and institutional inhibition of Phoenician commerce.

R. Museu Arq. Etn., 28: 1-30, 2017.

that used non-alphabetic, complex scripts, e.g. cuneiform glyphs. The knowledge of writing was restricted to small professional bodies of scribes, who were often trained to communicate in multiple diplomatic languages written in complex scripts (cuneiform, hieroglyphs). Literacy was the privilege of few specialists.

A change occurred by $1250 \mathrm{BCE}$, when the alphabet was adopted by Ugarit, a small state territorially and politically wedged between the 'Great Powers' of the day (e.g. Hatti, Mittani, Assyria and Egypt). The state of Ugarit standardized the alphabet and embarked on a monumental programme of producing all its local vernacular in it, using the cuneiform way of inscribing clay tablets (Sanders 2004). Intriguingly, Ugarit continued to produce its diplomatic and legal texts in other languages and scripts (Egyptian and Luwian hieroglyphs, Akkadian, Hurrian and Cypro-Minoan cuneiform). Cuneiform writing had until then been reserved for these foreign diplomatic languages. An extraordinary number of these tablets documenting the proto-alphabet have been discovered, throwing light on rare aspects of mythology, literature and ritual that would have been irrecoverably lost had these clay tablets not survived. With the fall of the state of Ugarit a century later, the alphabetic cuneiform disappears. For the next three centuries, the (archaeological, at least) visibility of the alphabet diminishes, being attested sparsely as inscribed graffiti.

Only from the $9^{\text {th }} \mathrm{c}$. BCE, does the alphabet regain prominence. Following the collapse of the Late Bronze Age imperial states (ca. $1200 \mathrm{BCE}$ ), with the new status quo in the Levant, the newly independent Phoenician city-states abandoned cuneiform Akkadian and hieroglyphic scripts as the official languages. Non-alphabetic scripts were marginalized, with the Phoenician city-states sanctioning instead the use of the alphabet.

The alphabet subsequently spreads in the Levant, but lacks monumental visibility. There are hardly any inscribed stelae proclaiming royal victories and power (few exceptions are found outside Phoenicia, e.g. Karatepe in Anatolia and the Nora in Sardinia). Instead, the small Phoenician city-states employ their new script for administrative purposes, using perishable materials as a medium, such as papyrus. These disintegrate quickly, leaving no direct archaeological evidence for the volume of text production. The evidence for the spread of literacy is indirect, through the casual uses of the alphabet (inscriptions on pots) and the competency and familiarity of its users that epigraphic testimonia even in the western Mediterranean manifest (Zamora López 2005).

Around the $9^{\text {th }}$ c. BCE, the Greeks adopted the script by the Phoenicians. By the following century, Greek-speaking people stretching from Macedonia to central Italy were already composing complex poetic verses and were inscribing them on vases during sympotic parties in impromptu actions (e.g. Tzifopoulos 2012). These activities reflect a casual use of the script, evincing familiarity and competence. In the Greek world of that period, silver was also lent with interest rates incurred, and the practice followed weighing methods (Kroll 2011). Hoards of silver/gold and their production areas have been identified in areas with clear mercantile links with the Phoenician world (Eretria in Euboea).

Similarly, in the Phoenician colonies of the western Mediterranean, the same is indirectly demonstrated by epigraphic testimonia (Zamora López 2005). Among Phoenician traders and crew ship members, the rate of literary was very high (cf. Amadasi-Guzzo 1992) on graffiti from Mogador, Morocco). By the $7^{\text {th }}$ c. BCE, for the first time in world history, the knowledge of writing had shifted from being the prerogative of a professional class of scribes, to becoming a popular skill. This revolutionized the ability and methods of communication but also cognition (Sanders 2004: 37).

Effectively, this means that a millennium had to pass before the alphabet spread.

Evidently, its supposed technological superiority (conferred by its alleged easiness of use) cannot explain its sudden spread in the $8^{\text {th }} \mathrm{c}$. BCE. The reasons have to be sought elsewhere. The alphabet moved from a marginal position to one of crystallisation and pre-eminence in two 
different episodes: during the rule of Ugarit and 400 years later, during the emergence of the Phoenician city-states as independent, i.e. in both cases when the alphabet became statesanctioned. Looked at from this perspective, it is immediately clear that the traditional explanation that the alphabet spread because of its 'superiority' (easier to learn), cannot explain its sudden spread centuries after its invention. What mattered was not some supposed innate superiority of the writing system (for example, that it was easier to learn), but instead the institutional framework that catalyzed its spread. The historical process of Phoenician commercial expansion provides the context into which these crucial problems of research can be combined to examine the process of the spread of alphabetic literacy and the paradox of a monetarized but currency-less Phoenician economy. The adaptation of the Phoenician alphabet into a syllabic script in southern Iberia supports this view. Ugarit's cuneiform alphabetic script emerged and disappeared within a specific institutional context. Can this disappearance be explained by the cumbersome nature of the script or was the collapse of the institutional context adequate for its disappearance?

\section{Aspects of monetization in Iberia from the introduction of coinage to the onset of the Roman conquest}

So as to understand what type of medium of payment and what types of transactions were used in commercial exchanges in the Iberian Peninsula, from the time of the Phoenician colonization in the late $9^{\text {th }} \mathrm{c}$. BCE, we have to look at the evidence for both the preceding and the following periods. This entails identifying traces of the putative metrological systems employed in weighing metal in the series of coinage issues minted at Classical and Punic mints. In the classical period, which probably reflects a comparable situation in the few centuries before it, Iberia was composed of different, ethnolinguistically, peoples (the Cantabri, Astures, Gallaeci, Lusitani,
Turdetani, the Levantine Iberi, the 'Iberi' from north of the Ebro River, the Celtiberi and the Celts), with different systems for establishing prices, means of payment and storing wealth (García-Bellido 2011).

On the basis of the archaeological and numismatic evidence, and taking into account solely the basis of index of value (not means of payment), the territory of South-central Iberia known in Roman times as Hispania can be considered fully monetized only by the $1^{\text {st }} \mathrm{c}$. CE (García-Bellido 2011). Across several regions of the Iberian península, pre-coinage forms of money included metal by weight, and this continued for centuries, in parallel with the use of coins.

The first coins were minted in the last quarter of $6^{\text {th }} \mathrm{c}$. BCE at the Greek colony of Emporion (Catalonia) in the territory of Indigetes, on the north-east Spanish coast, following prototypes from the colonists' metropolis of Phocaea in Asia Minor (Campo 2011; Chevillon 2011). A mint at the Greek colony of Rhodes (Roses, Girona) followed around $300 \mathrm{BCE}$, while the indigenous production of local silver coinage issues had to await the Second Punic War (Campo 2011). Montero Ruiz, Pérez \& Rafel (2011) investigated the origins of the metal used in the minting of indigenous coins in the north-eastern part of the Iberian Peninsula, based on the analysis of silver coins minted in Emporion, which contained silver from the south-eastern part of the peninsula (mainly from mines in Murcia) and from the south of France. The results of lead isotope analysis show a high level of mixed silver, pointing to importation of silver and lead supplies from southeast Iberia.

Further south in eastern Iberia, in Valencia, the discovery of $4^{\text {th }} \mathrm{c}$. BC hoards documents the use of both minted and unminted silver for payments. Coins, jewellery, both intact and in fragments, silver ingots and amorphous pieces of silver were used (Ripollès 2011). Even as later as the $4^{\text {th }} \mathrm{c}$. BC, the heterogeneity of forms of payment was dependent on distance from the coast (i.e. from the colonial world) and proximity to large settlements. It is only in the $4^{\text {th }} \mathrm{c}$. BCE, that the indigenous settlement 
"You give me letters instead of money?" Commercial transactions in the Near East and the Western Mediterranean ca. 1100-600 BCE: social innovation and institutional inhibition of Phoenician commerce.

R. Museu Arq. Etn., 28: 1-30, 2017.

of Arse (Saguntum, Valencia) mints coins, and only from the $2^{\text {nd }} \mathrm{c}$. BCE onwards, do silver coins begin to be used inland in this area (Ripollès 2011).

In south Iberia, the first coins arrived in the $5^{\text {th }} \mathrm{c}$. BC, and were the products of mints in the eastern and central Mediterranean (López Ruiz \& Ruiz Tinoco 2011). At the site of Malaka in Malaga, a region with cogent evidence for Phoenician settlement from the $8^{\text {th }} \mathrm{c}$. BCE, there is no evidence for the monetary use of metals prior to the $3^{\text {rd }} \mathrm{c}$. BCE, although five cubic bronze weights from a $3^{\text {rd }}$ c. BCE context shows an association with the earliest minted coinage of the town (Mora Serrano 2011).

In areas not directly touched by the colonial world, monetization emerges later. In central Spain, coinage and metal appears to have been used for payments. The Villarrubia hoard (found in Valencia or in Cuenca), probably dates to the $2^{\text {nd }} c$. BCE and consists in a trove of coins and fragments of silver (356 coins). The majority of these are Iberian imitations of fractional Emporitanian coins, but Roman coins, Hispanic-Carthaginian and others minted in Gadir, Arse and Massalia are also found (Chaves Tristán 2011). According to Rodríguez Casanova (2011) the modifications (fragmentation, perforation, clipping) made on $3^{\text {rd }}-2^{\text {nd }} \mathrm{c}$. BCE coinage found in the provinces of Guadalajara and Cuenca (Castile - La Mancha) may not be related to monetary practices, but instead reflect different customs arriving with Roman armies of different origins. In the north-west of the Peninsula, early monetization in the region arrives with the Roman army in the 1st c. BC (Vila Franco 2011).

Thus, Greek colonization in the north-east instigated the earliest issuing of coinage in the $6^{\text {th }} \mathrm{c}$. BCE, while regions colonized previously by Phoenicians (e.g. Malaga) do not issue coinage until centuries later. Both coinage and utensil money (jewellery, axes), as well as ingots and sheets of metal, were used concurrently for centuries in Iberia as a way of carrying out commercial transactions, probably in parallel with one another, at the largest commercial centres (García-Bellido 2011).

\section{A model for commercial transactions in Phoenician colonization}

\section{Methodology}

The seeming absence of currency use by the Phoenicians appears paradoxical, as it coincides with the expansion of their mercantile networks in the Mediterranean. This implies that whatever transaction system was used was considered efficient or flexible. Yet, the complexity and quantities of exchanges preclude simple, barter trade. Commercial exchanges entailed large consignments of shipped cargoes of multivariate bulks of mass-produced, standardised commodities. Instead of adopting a currency, the Phoenicians embarked on the standardization of balance weights, found from the Near East to the Atlantic. This commercial expansion correlates chronologically and spatially with the sweeping spread of the alphabet.

The spread of literacy is considered symptomatic of inventing an easy-tolearn script (the alphabet) and has been associated with commercial activities. Yet no convincing hypothesis exists as to the sudden popularisation of literacy nearly a millennium after the invention of the alphabet (e.g. Goldwasser 2011; Lemaire 2008; Sanders 2004). Since it appears that the alphabet was invented ca. $1700 \mathrm{BCE}$, a new explanation is needed for its sudden and sweeping spread in the $9^{\text {th }}-8^{\text {th }} \mathrm{c}$. BCE. Neither is there a persuasive explanation for how this transmission to the illiterate southern European people occurred.

The suggestion here is to relate literacy to the specific socio-economic framework, with particular attention to the role of the script within commercial transactions. Here I propose the following hypothesis that offers a coherent explanation and is supported by the archaeological eveidence, if not being corroborated by it beyond doubt: writing was used for commercial transactions, with written records of which kinds of commodities were exchanged for other kinds of commodities with the prices established by reference to metal (silver) weight. It is postulated that the alphabetic script played a crucial role in 
the Phoenician structures of economy by providing a writing-based system of carrying out transactions within the context of Mediterranean-wide networks (outside the Phoenician homeland which was embedded in the Near Eastern currents of metal-based monetary transactions). This system substituted a physical form of currency (e.g. pre-coinage forms such as weighted metal guaranteed by seals). The structural role of the alphabetic script within the Phoenician commercial exchanges that necessitated written accounts of transactions led to the swift and sweeping popularization of literacy in the $8^{\text {th }}$ and 7th c. BCE through the far-flung Phoenician commercial networks. This model finds parallels in Mesopotamia, since the cuneiform script was developed for record-keeping (Charpin 2010). For three millennia, the cuneiform was used predominantly for the complex account-keeping of the institutional and private economic sectors: orders, receipts, balanced account, legal texts and summary accounts of transactions (Baker 2003; Brosius 2003). Thus, the premise of the hypothesis is based on the fact that weighted metal did not always function as direct means of payment in Phoenician commercial transactions in the Mediterranean: weighted metal was not always exchanged but provided a standardised means of shared value. Such a way of estimating value and carrying out payments would require written accounts of transactions, specifying which kinds of commodities were exchanged for other kinds of commodities according to shared measures of value established in metal weight.

In order to test this, the hypothesis has been broken down into three sub-premises, to be examined as sub-topics. An inductive methodological model is followed so as to construct a model of how commercial transactions would have been carried out by Phoenicians in the Near East and overseas, the role of the alphabet within the system and the impact that this had on the popularization of literacy by: (1) determining if and what type of money was used by the Phoenicians in commercial exchanges; (2) assessing the possibility that a physical form of currency (iron spits, weighted pieces of metal) was routinely used for transactions; (3) evaluating the evidence for the possible use of script in transactions and (4) exploring the role of social and economic institutions in this process (the Temple, overseas sanctuaries, palaces, guilds). Sub-topic "Transaction mechanisms and the role of institutions in the Phoenician economy across the Mediterranean" will address (1) and (2), while sub-topic "Uses and users of the Phoenician alphabetic script in the Near East and overseas: the role of institutions in the popularization of literacy" will address (3). The synthesis of the two Topics and analysis of the results within their historical context will address (4).

Vital information could be added from a third line of investigation, the cuneiform archives. This here is presented in a summary format, so as to illustrate the potential of this line of research on the subject. The combined results can then test the overarching hypothesis. Their synthesis results in the proposition of a persuasive model on how commercial transactions would have been carried out by Phoenicians in the Near East and overseas and the role of the alphabet within that system.

Transaction mechanisms and the role of institutions in the Phoenician economy across the Mediterranean

\section{Aims and methods}

To address objectives (1) and (2) we need to allow for the multiplicity of different forms of monetary systems that may have been used and for spatial nuance in the regional patterns of the archaeological evidence for commercial exchanges. The inconsistencies in scholarly literature regarding the definition of 'money' lead to different interpretations of the same archaeological material, resulting in diverging viewpoints concerning the mechanisms of economy (e.g. compare Gitin \& Golan 2001, 2004 with Kletter 2003, 2004). Specificity must be introduced in the studies on regional patterns of conducting commercial transactions, 
"You give me letters instead of money?" Commercial transactions in the Near East and the Western Mediterranean ca. 1100-600 BCE: social innovation and institutional inhibition of Phoenician commerce.

R. Museu Arq. Etn., 28: 1-30, 2017.

which so far have not tended to differentiate between the monetary uses of silver with bullae (as a mark of guarantee of value) in Phoenician Tell Keisan (Israel), for example, from the barter trade that supposedly was conducted in the Phoenician West (e.g. Iberia). This entails the study of new contexts appropriate for the study of the monetary uses of metal and the reinterpretation of old ones, so as to determine if there was a marginal use of physical currency and whether regional patterns can be discerned. Taking as a departure point discourses on the reconsideration of the monetary systems in the Near Eastern archaeological record as outlined above, the investigation is to be guided by the following considerations:

- What is the evidence for the monetary uses of metal and their trading parters, e.g. do hoards attest to monetary uses of silver or other metals?

- Did other types of metal objects found across Phoenician sites in the Mediterranean/Atlantic (e.g. Mogador, Morocco) have a monetary function? - Are the patterns of the geographical distribution of balance weights, meaningful with regard to putative differences in transaction mechanisms?

\section{Data analysis}

The picture on how exchanges may have been carried out in the beginning of the Phoenician colonization, and earlier, during the closing centuries of the $2^{\text {nd }}$ millennium $\mathrm{BC}$ when the Atlantic Late Bronze Age trade brought into contact merchants from across northern Atlantic (Ireland, France) to Iberia is murky. The assumption of barter trade of metals exchanged for other products partly relied on classical period historiographers, such as Herodotus, but also on later authors describing Phoenician commerce on the Atlantic as a sort of primitive form of exchanges with hostile indigenous populations ${ }^{3}$. Arévalo

3 According to Herodotus (4.196), Carthaginian merchants carried out exchanges on the Atlantic regions by
González (2011) tentatively poses the question of the putative role salt may have played within this system of exchanges, starting from a passage in Strabo: (III, 5, 11) "the Phoenicians of Gadir exchanged skins, pottery, bronze containers and salt for lead and tin from the Cassiterides". On the other hand, archaeologically, the discovery of hoarded metal with unminted silver fragments, a kind of pre-coinage, on several points across the Mediterranean coasts of Iberia, appears to have led over time to the formalization of the use of cut silver by weight for at least some of the exchanges, often postulated on the basis of discovered balance weights.

Balance weights have been found at colonial and indigenous sites in south Iberia. In general, the study of this class of artefacts in Iberia is wanting, as lumps of corrugated metal often are not identified correctly $y^{4}$. Balance weights inscribed with Phoenician letters have been identified from the Phoenician colonies at Cerro del Villar and (Malaga) and Castello de Doña Blanca (Zamora López in press).

Several specimens are known from hilltop settlements in an area crisscrossed by the fluvial waterways formed by the Tagus, Mondego and Aveiro in Beira (central Portugal) in southwest Iberia. Vilaça (2011) studied 26 objects interpreted as weights from different sites in Portugal, south of the Douro River at settlements in the Beira Interior, specifically at Morereirinho and Monte de Trigo (Idanha-Nova, Castelo Branco) and Pragança (Cadaval, Estremadura). Most of these balance weights came from the last two indigenous settlement sites. The region corresponds geographically to the area where

leaving on the beach the commodities to be sold, retreating onto their ships until the locals had taken the commodities and left in their place produce with equivalence of value, all the while communicating with smoke signals until the transaction was completed (Pappa 2013: 132-135)

4 From the post-Orientalising Southern Alentejo necropolis of Galeado, an indigenous necropolis with few Phoenicianstyle imports, a conical and hollow lump of gold (1.1. x 0.6 cm; AU 984, National Museum of Archaeology, Lisbon) has been listed as potentially part of an earring, but such broken pieces of noble metals may also have been used in exchanges. 
Phoenician and Orientalizing evidence has been traced, probably indicating commercial exchanges, as opposed to demonstrating the urban colonial intensity found on the Mediterranean coast.

According to Vilaça (2011), the metrical system employed by these objects approaches most closely that of Ugarit $(9,3-9,4 \mathrm{~g})$. The same author allows for the possibility that such balance weights are represented in the south-west stelae of the Iberian Peninsula, the first phases of which traditionally have been dated to the period before the onset of the Phoenician colonization. These stelai are monumental, found in isolation and often depict anthropomorphic figures surrounded by hoards of objects (from fibulae and combs to chariots and musical instruments). They are thought to iconographically reflect exchanges with the Near East or other parts of the eastern Mediterranean during the end of the Late Bronze Age, prior to the Phoenician colonization. In a similar spirit, Ruiz-Gálvez Priego (2008) argued that that balance weights attest to exchanges with the eastern Mediterranean during the $2^{\text {nd }}$ millennium BCE, to which period she dates the emergence of the local South-western script, postulating widespread literacy among Near Eastern traders and merchants. This author postulates literacy on the basis of the archaeological documentation for tools and implements for writing (such as wax tablets and stylus, e.g. at the $12^{\text {th }} \mathrm{c}$. BC Uluburun shipwreck) in the eastern Mediterranean. Despite making the association between merchants and the 'democratization' of literacy through the alphabet, the author does not find a reason to connect the skill of learning how to write with the commercial exchanges per se, assuming that transactions would have involved numeracy and not literacy (Ruiz-Gálvez Priego 2008). In a later article, Ruiz-Gálvez (2014: 174-175) considers these balance weights metric units not of the Ugaritic shekel, but the Egyptian qdt, which was used across the northern and Southern Levant in the Early Iron Age. Recruiting other types of evidence for exchanges with the Near
East in this Portuguese region, such as the so-called Cabeço da Maria Candal (Beira) hoard containing tools of Atlantic typologies (palstaves, axes, a chisel) and likely imported from the Near East metalsmith's tongs, the author postulates the local adoption of Near Eastern units of exchange by the locals (RuizGálvez 2014, 175, Fig. 135).

Against the hypothesis of $2^{\text {nd }} \mathrm{BCE}$ millennium contacts argue the evidence for long-lasting, widespread and convertible metrologies in commercial exchanges that continued well into the $1^{\text {st }}$ millennium $\mathrm{BCE}$, since "the different main Levantine shekels, the shekel 'of Khatti' (11,75 g, h), the shekel 'of Ugarit' $(9,4 \mathrm{~g}, \mathrm{~s})$ and the shekel 'of Karkemish' over time became widespread and interconnected with a simple ratio between them; they were counted also, in case of necessity, on a decimal and sexagesimal basis. Also the 'Mesopotamian' shekel was widespread in Syria and Palestine from the beginning of the II Millennium BC" (Alberti, Ascalone \& Peyronel 2006: 1-3).

Another strong argument against a $2^{\text {nd }}$ BCE millennium date for these weights and the South-Western script, is that the majority of epigraphists consider that the South-Western syllabary (Valério 2008, 2016; Zamora López in press) developed in Iberia following contacts with Phoenicians in the early $1^{\text {st }}$ millennium $\mathrm{BCE}$. The syllabary is known from a different group of stelae that are found in South-Western Iberia, but appear to be later than the ones described above. They are iconographically poorer but present inscriptions in this undeciphered script.

Several questions become then pertinent: Was the north Syrian metrology extinct after the fall of the Ugarit or had it become so wellintegrated into other metrologies that its use continued in the $1^{\text {st }}$ millennium BCE Levantine areas? What kind of notations and counting do we envisage? How do we envisage the counting and notations for commercial purposes? Would these consist solely in numbering quantities

5 The same hoard is published as coming from the site of Freixianda (Ourém) by Vilaça (2013: 25). 
"You give me letters instead of money?" Commercial transactions in the Near East and the Western Mediterranean ca. 1100-600 BCE: social innovation and institutional inhibition of Phoenician commerce.

R. Museu Arq. Etn., 28: 1-30, 2017.

and prices? Would it not require information on merchants, recipients, destinations and name of products, commodities to be sold or exchanged, payment received, payments delayed, tax and interest?

Other types of metal items found may have held a monetary function, having been used as a store of wealth or means of exchange. Several hoards with eastern Mediterranean/Near Eastern elements have been found in Iberia: the Villena hoard from Rambla de Panadero in Alicante and the Berzocana found in Cáceres. The first probably dates to pre- $8^{\text {th }}$ c. BCE, and contained elaborate, some repaired, gold and silver objects (ca. $10 \mathrm{~kg}$ ), such as Atlantic torques and golden copies of the local types of Cogotas I ceramic open vessels (bowls), yet clearly made with Near Eastern craftmanship (Pappa 2013: 27-28; Ruiz-Gálvez 2014: 171).

The Berzocana hoard was made up of an eastern Mediterranean-style, bronze bowl and two golden torques. These are stylistically Atlantic but their manufacture involved Near Eastern techniques. Their weights, $750 \mathrm{~g}$. and 950 g. respectively, have been correlated to the Late Bronze Age Hatti's shekel metrology (11.75), as a 6.5 times and 8 times multiple respectively (Ruiz-Gálvez 2014: 171). It is clear from the stylistic and technological content of these pieces that they attest to contacts between Iberia and Near Easterners. The collection of these items together also suggests that such 'treasures' may have been conceived of as a way of storing wealth through precious metal. Unless the 'metrology' of the torques is accidentally a multiple of the Near Eastern shekel weight, we can take this argument further and espouse Ruiz-Gálvez' hypothesis (2014) that they may have held a monetary function, i.e. as an index of value and/or direct means of payment. Given, however, that the dates of these hoards remain uncertain, perhaps they fall into the context of precolonial Cypriot expeditions to the region (Pappa 2013: 27-29).

In additions, iron spits, have been found at the Phoenician site on Mogador, a seasonal Phoenician commercial base, off Essaouira in Morroco ${ }^{6}$. The hypothesis of a monetary value has a twofold basis. It is supported by iconographical renderings in Assyrian reliefs depicting long spits carried by retinues of men in tribure scenes, while the monetary use of iron spits (oboloi) in pre-coinage, Archaic Greece is well established. Could the specimens in Mogador have been used as physical currency? Other utilitarian objects encountered in the archaeological record of Phoenician period Iberia may have played a monetary role. For example, fibulae, widely present across south-central Iberia in various styles, may have been used as exchange currency (Salete da Ponte 2001: 540). Other metal finds have been found at sanctuaries on the Atlantic littoral of Iberia (Gomes 2012), some of which may have held monetary values.

To sum up, it is clear that the process of monetization remained patchy for centuries in Iberia. Different forms of money were used as late as the onset of the Roman conquest: scrap metal, ingots, later coinage introduced by the Greek colonies etc. For the early 1st millennium BCE, the evidence requires a more nuanced perspective as to the forms that money could have taken. The coinage that becomes available from the $6^{\text {th }} \mathrm{c}$. BCE onwards and spreads gradually and in patches across Iberia is characterized by different metrological systems (García-Bellido 2011). These may underlie the different metrological systems of regional balance weights used in previous periods. Balance weights identified at the 6th-4th c. BC sanctuary complex of Cancho Roano (Zalamea de la Serana, Badajoz), for example, are based on Tyrian weighing systems that arrived through Gades and spread north and west in the Peninsula. By contrast, Greek coinage from Emporion was based on the Phocaean metrological system while the Edetan and Contestan (corresponding to the modern Murcia and Valencian territories, respectively) coinage series probably relied on an autochthonous metrological systems (García-Bellido 2011).

6 For the excavations, see Marzoli \& El Khayari (2009; 2010). 
Uses and users of the Phoenician alphabetic script in the Near East and overseas: the role of institutions in the popularization of literacy

\section{Aims and methods}

Particular sets of questions relating to the reasons that drove the popularization of the alphabet within Phoenicia and the processes that resulted in its spread outside the Near East should be explored, departing from the following:

- What types of archaeological sites (commercial, religious etc) attest to widespread professional/lay literacy?

- What were the uses to which the Phoenician alphabet was put?

- Are there regional patterns of variation in script types and script uses?

- What is the relationship of the so-called traders' marks with writing, e.g. notational symbols?

- What were the mechanisms of the spread of literacy?

- Can we discern a geographical variation in the mechanisms of this spread in areas where the script is known to have been adopted and adapted?

- Can the literary/other type of written speech of the receiving society elicit information on the ways the adoption of the script occurred (e.g. the function of stelae bearing the South-Western script in Iberia)?

- Can the mechanisms or institutions behind the spread of literacy be archaeologically substantiated or is their existence only hypothesized (e.g. scribal guilds attached to the Temple or overseas sanctuaries)?

\section{Data analysis}

Epigraphic evidence includes the corpus of Phoenician epigraphic testimonia and those in the South-Western script, monumental or not $^{7}$. The corpora of Phoenician epigraphic

7 Various corpora of Phoenician-Punic inscriptions have emerged over the past years (Cunchillos et al. 2000). The testimonia are limited for the period under study, and include funerary inscriptions, inscriptions on votives (rarely) and most commonly inscriptions on pots, to mark possession of the object or of other types. The low number of extant finds appears to be in inverse proportion to the actual voluminous records of Phoenician text production, which have not survived (Zamora López 2005). The fragmented record of Phoenician graffiti attests to widespread literacy evinced through writing on local materials and graphic traits showing facility in using a ductus on perishable materials (e.g. parchment), with ink (Zamora López in press: 8 ). Hard materials were less commonly used, e.g. by inscribing pots. The use of ink for pot inscriptions and the discovery of cretulae for sealing papyrus letters leads to the speculations that most of the matrixes for seals should have been used for administrative/legal documents (Zamora Lopéz in press).

Most non-funerary evidence comes from Phoenician settlement sites, e.g. the site of "Teatro Cómico" in Cadiz, the Castillo de Doña Blanca and Tavira (Zamora Lopéz in press). Other contexts include sanctuaries (such as the inscribed Egyptian statuette deposited at the Carambolo sanctuary) and commercial sites, where inscribed pot fragments and equipment for writing have been found, e.g. the discovery of writing utensils in a $9^{\text {th }}-8^{\text {th }} \mathrm{c}$. BCE commercial deposit of Phoenician workshops in Huelva (Spain) found in a locality where a Phoenician sanctuary had been excavated previously (Amadasi-Guzzo \& Zamora 2008; González de Canales Cerisola et al. 2006; Belén Deamos 2009: 196-197). The corpus of graffiti from Mogador, the seasonal trading post off Essaouira (Morocco) is one of the largest in the West, with over 300 fragments, despite the lack of structures at the site (Pappa 2013: 90-91). The inscriptions are personal names, likely marks of ownership, with originas in the milieu of Tyre and Sidon, as well as Israel, Philistia and Moab (Amadasi-Guzzo 1992) Some of the

DataBank of the Phoenician and Punic inscriptions (for a description see: Xella \& Zamora López 2007) was not available at the time of writing this. 
"You give me letters instead of money?" Commercial transactions in the Near East and the Western Mediterranean ca. 1100-600 BCE: social innovation and institutional inhibition of Phoenician commerce.

R. Museu Arq. Etn., 28: 1-30, 2017.

inscribed pot fragments constitute evidence for administrative usage. Two such have been found at Castillo de Doña Blanca, one which may record some calculation, and another at the site of Tavira, a settlement site with a sanctuary, use for administration purposes (Amadasi-Guzzo \& Zamora 2008; Zamora López in press). Other graffiti are found on amphorae and may be linked to information for commercial purposes, denoting e.g. senders or destination, or other times they were "mercantile codes and notations" according to Zamora López (in press).

High literacy in commercial contexts is well evinced. On Mogador the casual inscribing of names on pots to mark out personal possessions in the temporary conditions of communal living demonstrates the high degree of literacy among Phoenician crews of merchants, sailors and perhaps craftsmen. Could literacy have been part of exercising the profession? Mogador shows the connection of commerce with widespread literacy, and if the spits had monetary value, with the context of direct commercial exchanges too.

Evidence for literacy thus maps out well on patterns of commercial exchanges. The alphabet spreads and is subsequently adapted into the South-Western script. Inscriptions in both Phoenician and South-Western script at Tavira may show some of the earlier forms of adopting the Semitic syllabary for the local language, which then found new uses in the wider territory of South-Western Iberia, being monumentalised on the stelae. Such epigraphic testimonia highlight the role that the alphabetic script had in commercial exchanges and account-keeping, leaving open the possibility that personnel and resources were provided by Phoenician sanctuaries, the only institution well-documented archaeologically in the Phoenician archaeological record of Iberia.

\section{On the role of institutions}

The development of models from the scope of economic history have advanced our knowledge regarding market mechanisms in Phoenician commerce (e.g. Moore \& Reid 2008; Pappa 2013). A clear picture of the agents and institutions behind the expansion of commercial networks is lacking, though emphasis has been placed on the commercial functions of sanctuaries (Belén Deamos 2009; Grottanelli 1988; Marín Ceballos \& Jiménez Flores 2004; Ruiz de Arbulo 2000). This allows us to see the 'Temple' in the Phoenician city-states of the Near East as an economic agent, and assume that independent 'Temple-like' institutions existed throughout the Mediterranean with comparable commercial functions.

This is of crucial importance as there is a discrepancy between the archaeological evidence (especially in Iberia) for a wide and dense network of marine sanctuaries dedicated to Phoenician deities, with attached commercial functions on the one hand, and the postulation of private, profit-driven initiatives as spearheading the Phoenician commercial expansion, on the other. The latter supposition is based on textual sources from the previous period (e.g. the $11^{\text {th }} \mathrm{c}$. BCE Egyptian payrus of Wen-amon) and the archaeological evidence for the trade routes, agents and commodities in which Phoenicians were implicated.

Studies on the organization of Phoenician commerce allude to the role of the 'Temple' and 'private entrepreneurs' without differentiating between the 'Temple' in the Phoenician city-states of the Near East and those in the West, or clarifying whether independent 'Temple-like' institutions existed in the Phoenician centres of the Mediterranean with comparable commercial functions. Preliminary research on the possible role of the sanctuaries in Iberia has drawn attention to their role in providing resources and financial capital (e.g. Marín Ceballos \& Jiménez Flores 2004; Ruiz de Arbulo 2000). Such studies have to content at the moment with textual information from the Greco-Latin sources juxtaposed onto the earlier archaeological record. The contemporary archaeological and epigraphic evidence has not been mined (let alone in tandem) for this type of information 
regarding the organization of Phoenician commerce. In Iberia this is explained by the fact that the archaeological evidence for sanctuaries is the fortuitous result of mainly recent excavation projects.

The comparison of primary epigraphic and archaeological material from Phoenician commercial settlements across the two geographical extremes of the Mediterranean allows us to discern that religious institutional structures existed across the Phoenician maritime networks, perhaps with concomitant professional structures, such a scribal schools based in sanctuaries and guilds of craftsmen organized in sanctuaries etc. Phoenician sanctuaries across the Mediterranean and the Atlantic fringes have yielded evidence for the role of sanctuaries in commercial activities. The sanctuary of Astarte at the Phoenician colony of Kition (modern Larnaca) in Cyprus (Karageorghis 2005; Amadasi-Guzzo \& Karageorghis 1977) was associated with metallurgical production, probably overseeing trade in copper and/or other metals. Archaic Phoenician inscriptions from Kition attest to the presence of scribal schools, in addition to earlier inscriptions on votive items

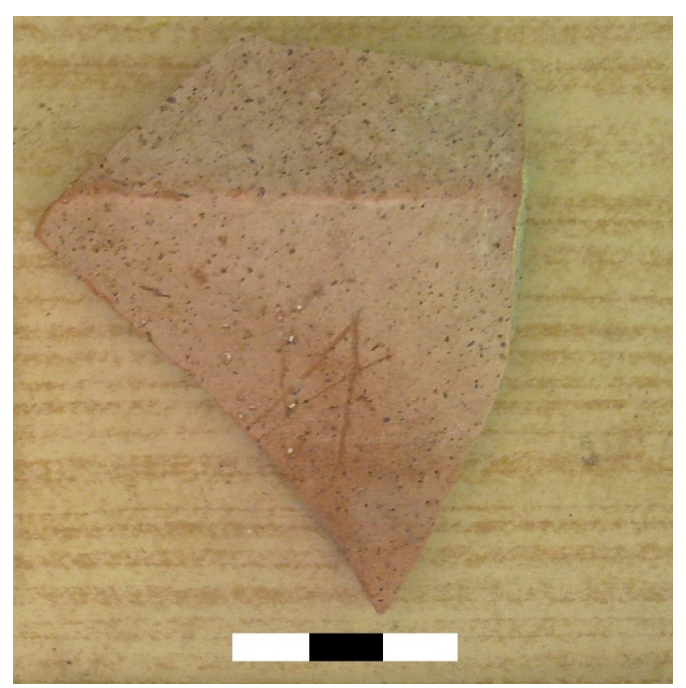

Fig. 2. Pottery fragment preserving part of a Phoenician letter (?), [806] context, Átrio 1, Pit 2/ 'Túmulus' 2, level 10, Palácio da Galeria, Tavira, probably $8^{\text {th }}-7^{\text {th }}$ c. BC.

Source: Author. attesting to literacy (Dupont-Sommer 1970). One neglected find is a $6^{\text {th }} \mathrm{c}$. BCE limestone tablet in cursive Phoenician found in the harbour area of Kition, recording lists of payments to be made to various employees of the sanctuary, including scribers and barbers, to deities and to sailors ([CIS nos 86A, 86B], Healey 1974). At the other end of the Mediterranean, Phoenician sanctuaries are associated with production and/ or commercial activities too (e.g. Mayet \& Silva 2000). At the sanctuary excavated in Tavira (Pappa 2015b;), there is some evidence that metallurgical activities took place at the sanctuary zone in Tavira too. In Tavira, the $7^{\text {th }} \mathrm{c}$. BCE administrative text from the site was incised onto an ostracon, originally part of a locally-made pot (and so in all probability inscribed in Portugal). Several other fragments document inscriptions in the Phoenician (Fig. 2; Fig. 3) and the SouthWestern scripts. Further north on the Sado estuary, the small Phoenician sanctuary at Abul is a typical establishment of the cult-commerce type (Mayet \& Silva 2000). Several other such cult centres are encountered on the Atlantic coast of Iberia during the Phoenician period (Gomes 2012:, 23-107).

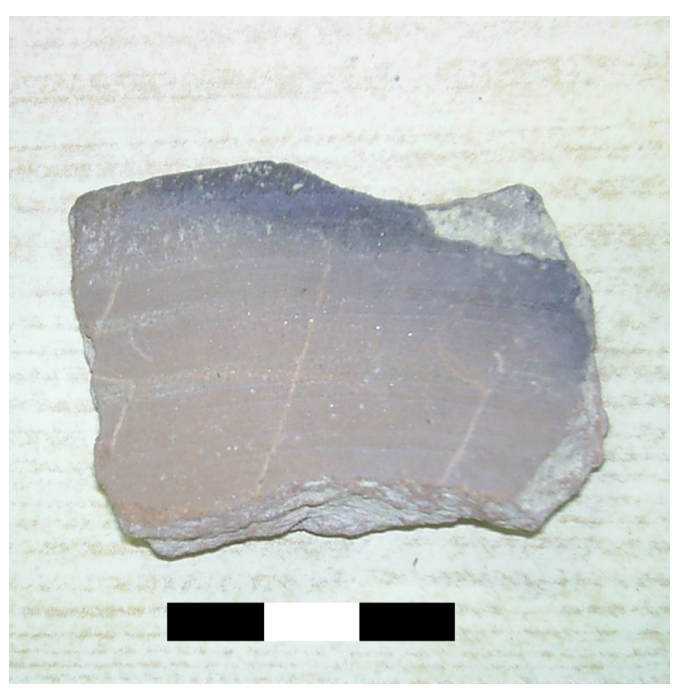

Fig. 3. Pottery fragment, brown slip, graffiti in Phoenician, registration GL-99-11-8, probably fro, Átrio 1, Tumulus 1, layer 4 (likely $8^{\text {th }}-7^{\text {th }}$ c. BCE), Palácio da Galeria, Tavira, from secondary context.

Source: Author. 
"You give me letters instead of money?" Commercial transactions in the Near East and the Western Mediterranean ca. 1100-600 BCE: social innovation and institutional inhibition of Phoenician commerce.

R. Museu Arq. Etn., 28: 1-30, 2017.

In the Near East too, sanctuaries also seem connected to production and commercial activities. Sanctuary complexes of Phoenician-Syrian affiliations in the Transjordan at Kuntillet 'Ajrud ( $9^{\text {th }} / 8^{\text {th }}$ c.) in the east Sinai and at Deir 'Alla Phase M / IX, for instance, appear to have been textile production centres and have yielded plenty inscriptions, while abecedaries have also been found (Boertien 2007), though a religious function for the latter cannot be excluded ${ }^{8}$. For the Greek world, suggestions for the economic role of sanctuaries, as "receivers, repositories and disseminators of metal able to be minted" are based on literary sources and archaeological material of coinage and metals deposited at sanctuaries (Domínguez Monedero 2011).

Cult fostered the Phoenician commercial expansion, by providing resources, probably including capital for investment and mediating in foreign lands under the patronage of deities as means of safeguarding transactions (Pappa 2015c). This commercial role of the sanctuaries sheds light on the institutional role of sanctuaries in the dissemination of the alphabet, which would have been used in commercial activities, leading over time to the popularization of literacy. In the Phoenician world, however, it appears that the conservative nature of the religious-economic institutions, in tandem with the efficacy attained by the existent system of exchanges, hindered the progression to a true currency-based economy.

Economies at contact: Phoenician economic exchanges in the Near East through the Assyrian records

We lack any records the Phoenicians themselves may have compiled on economic transactions. However, a large part of the economic and legal texts of the contemporary Neo-Assyrians, commercial partners of the Phoenicians, have survived, as have the later Neo-Babylonian texts. These archives add

8 An alphabet was inscribed on the rim of a bowl at Deir Alla and four found at Kuntillet 'Ajrud (Boertien 2007; Shea 2012). lines of investigation that can augment our understanding of the Phoenician economy regarding the workings of contemporary Near Eastern economies and mechanisms of exchange.

Although the Assyrian archives provide the most direct and rich source of documentation for the way society was structured and economy worked in an ancient Near Eastern economy including the period under discussion (900-600 BCE), comparative insights have not so far been explored for the examination of similar questions in neighbouring cultures due to artificial disciplinary boundaries. Textually, the role of Cyprus has been analysed from the perspective of the archives (e.g. Cannavò 2007) but an interdisciplinary and regional focus is glaringly missing. For Mediterranean archaeologists, on the other hand, the information of the Neo-Assyrian scholarship is viewed as inaccessible. And yet a lot of the legal texts of the $8^{\text {th }}$ and the $7^{\text {th }} \mathrm{c}$. BCE contain vital information regarding the Phoenician economy, including the possible impact of metal currency on the Phoenician economy and its deflation through imported (via the Phoenicians?) metals.

Direct examination of the Neo-Assyrian economic system vis-à-vis the Phoenician economy remains an un-attempted feat. Thus, the rich scholarship on market mechanisms evinced through these archives has ignored the interrelationship of the coastal Levantine economies with Assyria, entangled through political control, overlordship and trade. Such comparative studies are sadly missing due to entrenched mentalities in different disciplinary fields (Mediterranean archaeology, Assyrian history and Phoenician epigraphy), which however treat chronologically and spatially congruent data, and therefore are vital to understanding the economic interrelationships between different entities in the ancient Near East.

These Near Eastern archives were the result of documenting, processing and storing information of economic character, including payments between private parties, tax payments, letters stipulating orders and receipts for the exchange of goods and livestock, characterised by the copious production of copies of these tablets, and their periodic compilations in 
summary accounts (Brosius 2003: 1). These systems of exchange start becoming increasingly sophisticated gradually from the 3rd millennium onwards, but do not radically alter their character for millennia. In Babylonia, by the 6th c. BCE there was still reliance on written documentation, to the extent that extant documentation of account-keeping archives is conducive to a highly detailed understanding of the economy (e.g. Jursa 2010, 2015). This demonstrates that several Near Eastern economies relied on the written record for their functioning.

A comparative work with the largely contemporaneous with the Phoenician expansion Neo-Assyrian texts would rely on the study of appropriate collections, including online databases, addressing questions aiming at elucidating the structures and mechanisms of Phoenician economy by providing an added line of indirect documentation. The study of Neo-Assyrian archives can take further existing work in the field, examined from the perspective of the information Assyrian state archives can yield regarding the Phoenician economy and its interaction with Assyria. They ought to be mined for information regarding the way Phoenician commercial exchanges were conducted, allowing for information on how their Phoenician partners may have carried out transactions with them, including more broadly crucial information on the structures and working of the Phoenician economy (e.g. private and templeorganized commerce, exchange mechanisms).

Several questions on the structure of the economy could be explored. What can the archives tell us about Phoenician commercial exchanges with the Assyrian institutional sector? Can we differentiate between private and institutional commerce with Phoenicians and between commercial and vassal types of exchanges? Is there any documentation for Phoenician commerce with the private sector? Can price fluctuations in metal (e.g. deflation) in the Assyrian economy be correlated with imports via the Phoenicians? Can this textual evidence be correlated with the archaeological evidence? For instance, it is accepted in current scholarship that at the closing end of the $2^{\text {nd }}$ millennium BCE there was a rapid increase in Babylonian prices in silver, explained either through rapid decreased supplies in a general climate of economic malaise or oversupply-caused silver deflation (Kleber 2016). In addition, the Assyrian state archives document that copper, bronze and silver were used as currency. Through the study of legal texts, it is known that copper and bronze were used extensively in the $8^{\text {th }} \mathrm{c}$. BC and only began to be replaced with silver in the $7^{\text {th }}$ c. BCE, following Sargon's II aggressive campaigns against the Phoenician city-states. Effectively this led to price fluctuations and eventually a deflation in the price of silver (Radner 1999, 128-129). From a Mediterranean archaeologist's perspective, these trends can be correlated with the intense Phoenician commercial activities in the silver mines of south Iberia (in Rio Tinto and Aznalcóllar) (Pappa 2013). Yet such information deriving from contemporary Assyrian texts is often considered impervious by Mediterranean archaeologists due to increasing specialization and stark disciplinary boundaries. Cross-fertilization between the two fields is much needed.

\section{A new model on Phoenician transactions and the spread of literacy}

The Synthesis of the results of the three lines of investigation aims to respond to the central hypothesis with a new model on the historical relationship between the sudden and swift explosion of alphabetic literacy, the monetary system employed in commercial networks and the socio-political contexts into which these processes developed. The different lines of enquiry, all addressing sub-questions within the overarching research framework come together to test the hypothesis that causality can be established between the popularization of literacy and the absence of currency use in the Phoenician commercial networks. The model internally supports the interrelationship between the sudden spread of alphabetic literacy, the monetary system(s) employed in commercial networks and the socio-political contexts into which these processes developed. An integral aspect of this endeavour is the outlining of the specific mechanisms and factors that led to the 
"You give me letters instead of money?" Commercial transactions in the Near East and the Western Mediterranean ca. 1100-600 BCE: social innovation and institutional inhibition of Phoenician commerce.

R. Museu Arq. Etn., 28: 1-30, 2017.

earliest popularization of literacy. New concepts that take into account the multiplicity of different forms of monetary systems have been employed. The outcome of the Synthesis is presented here as a new model of ancient monetary practices in the market-based commercial networks of the Phoenicians and their relation to literacy in the $1^{\text {st }}$ millennium BCE.

Phoenician trade was a well-organized business, relying on private capital as well as being in part state-sponsored. Through a horizontal network of producers of commodities, packaging material and traders, commercial operations thrived and expanded from the territory of what is now Lebanon to the Atlantic coast of Portugal and Morocco. Regarding the level of sophistication in the Phoenician economy and trade, we know that we are speaking of transactions involving large consignments of shipped cargoes consisting of various mass-produced commodities in bulk. There are many reasons why a commercial system with far-flung networks would have departed from contemporary transaction systems in the Near East, even if limited to its overseas operations, e.g. because the Early Iron Age Mediterranean societies lacked the sophisticated exchange system documented in the late $2^{\text {nd }}$ and $1^{\text {st }}$ millennium BCE Near East.

A type of market-based commerce using phenomenally barter trade but actually employing as a type of currency substitute written accounts based on shared measures of value established in metal (as a form of 'money') would offer an explanation for the different monetary practices of the Phoenicians, who unlike other Near Eastern people were actually interacting with many different societies outside the Near East. How else would transactions of multivariate bulk commodities take place? By individually and instantaneously exchanging each amphora and log of wood or ingot of metal with animal skins or foodstuffs? These were not low-level exchanges between members of prehistoric villages, as are implicitly treated in the scholarship, but part of a sophisticated exchange system relying on market mechanisms.

The transactions, according to this model, were carried out using written records of which kinds of commodities were exchanged for other kinds of commodities in large-scale commercial exchanges. The means of payment could have been weighted metal, to be paid instantaneously or in the future, once the transaction had been completed, conceivably through series of intermediaries. While the value of commodities was made using silver as index of value, the means of exchange may not have always been silver or some other metal, whether uncut or in jewellery form. Commodities could have been exchanged with other commodities using a standard reference of value. For such transactions, written accounts would need to accompany the purchasing and selling business of commercial agents, necessitating the spread of literacy. Balance weights would have been used in the transaction where metal was used as a means of payment. Often their discovery is interpreted as evidence for transactions involving weighted metal, ignoring that they may have been used for other purposes, e.g. to weigh rare spices, whose importation in the Near East from the Late Bronze Age onwards is documented in the archaeological record (Stockhammer 2016). In terms of the criteria used to define currency sensu stricto, the use of silver as an index of value and means of exchange would still not fulfil the characteristics of currency, for which the guarantee of the issuing authority is needed.

Previous hypotheses have suggested that the alphabet spread as an 'accompaniment to trading transactions', but in oblique ways, with its spread considered symptomatic of traders living in foreign places and bringing customs. Analogies, pragmatically, with contemporary and overlapping commercial systems in the Near East suggest otherwise. The Babylonians made use of securities, that is promissory notes, which served some currency functions. For the Babylonians the absence of currency is not a paradox, for their securities in combination with silver fulfilled some of the functions that currency plays.

The novelty of the present idea in the proposed model is that it sees the spreading of literacy not as a mere 'accompaniment' to trade, but as an element that played an institutional role within the system of transactions. The present model differentiates between language 
and script, treating the basis of the hypothesis to be literacy, and does not confound it with numeracy, which has been a hypothesis previously explored.

A similar process of monetization evolved centuries later, in the northern frontier zones of the Roman empire (Limes). During the early phases of the monetization of Rome's frontier provinces, transactions may have involved seemingly barter trade (commodities exchanged for produce or services) but "the transaction was reckoned on both sides in monetary terms, even if cash did not always exchange hands. In addition, the use of credit extended the monetization of the local economy beyond the limits of the actual quantity of coins in circulation." (Katsari 2010: 243). In the case of the Phoenician economy, the role of the creditgiving institutions could have been played by the temples. The structural role of the temples in the Phoenician commercial network continues to be suggested by archaeological projects that identify religious buildings in crucial nodes of the commercial sphere (see Pappa 2015a).

\section{Final words}

The proposed model is not based on a hypothesis that can be confirmed if only one day we would embark on finding troves of material recording commercial exchanges recorded in some script. Rather, conducting the contextual analysis of the evidence for the uses and users of the script, a strong correlation is detected between literacy and commercial settings, complemented by the evidence for the monetary use of metals in Iberia and the mechanisms of contemporary Near Eastern economies.

In an archaeological project, the biases of preservation and discovery are an inherent problem of the archaeological record (and consequently, of the epigraphic, which falls into it from the perspective of preservation and discovery), it forms one of the premises on which archaeology works as a discipline. As an inherent problem the discipline, it is a non-negotiable condition with which archaeologists grapple and thus part of every archaeological project. The reason why archaeologists do not simply classify pots, stones and other broken pieces of material but work towards reconstructing past socio-cultural and economic systems is also the reason why in archaeology the capacity to move from one level of basic-data information to more abstract concepts is absolutely necessary. Otherwise we would be stuck with pots, and stones and other broken pieces of material culture, rather than converting this information into sociocultural and economic history. In archaeology, the importance is placed on the degree of likelihood, so it is possible that the central hypothesis will never be corroborated or verified beyond any doubt. Despite limitations, this model results in a plausible, logically coherent and largely archaeologically documented picture of the way Phoenician commercial exchanges operated as a whole in the colonial world of the far west.

\section{Conclusions}

The present article puts forward a new model that identifies and explains the economic and social mechanisms that led to the spread of the alphabet from the Near East to the Mediterranean ca. $850-700$ B.C. It tests the hypothesis that the alphabet played a crucial role in the Phoenician structures of economy by providing a writing-based system of carrying out transactions within the context of Mediterranean-wide networks that substituted a physical form of currency, thus leading to the spread of literacy in the $8^{\text {th }}$ and $7^{\text {th }} \mathrm{c}$. BCE.

The analysis and interpretation of the evidence are structured along the threefold hypothesis that a type of market-based commerce using phenomenally barter trade but actually employing as a type of currency substitute written accounts based on shared measures of value established in metal (as a form of 'money') explains the different monetary practices of the Phoenicians, who unlike other Near Eastern people were actually interacting with many different societies outside the Near East and needed complex systems 
"You give me letters instead of money?" Commercial transactions in the Near East and the Western Mediterranean ca. 1100-600 BCE: social innovation and institutional inhibition of Phoenician commerce.

R. Museu Arq. Etn., 28: 1-30, 2017.

of adaptation. This system of commercial exchanges finds parallels in the Near East already from the 3rd millennium BCE. Within the institutional role of the script in the Phoenician expansion into the Mediterranean, we can rehabilitate the role of the literacy, as something more than casual intercultural contact in the spirit of 'diffusion' theories.

\section{Acknowledgements}

Research for this article was carried out within the post-doctoral research project "Mecanismos comerciais, monetização e alfabetização no Mediterrâneo e no Oriente Próximo: inovação social e inibição institucional do comércio fenício", funded by the Sao Paulo Research Foundation (FAPESP).
I would like to thank warmly Dr. Manuel Maia, Director of the Museu da Lucerna in Castro Verde, for giving me access to the finds and archives from the completed excavations of Dra. Maria Pereira Maia, who had headed the Campo Arqueológico de Tavira, when I had the chance to carry out short fieldwork in 2012 and 2013, thus permitting me to contextualize the bulk of the finds studied in Tavira with the permission of the Câmara Municipal de Tavira subsequently.

For the generosity in sharing his expertise I would like to warmly thanks Prof. C. Schmitz (Eastern Michigan University), who took the time to examine and discuss the graffiti briefly presented here at great length. I also owe gratitude to Dr. Miguel Valério (University of Barcelona), who very kindly and generously agreed to examine the corpus at an earlier stage of research, pointing me towards the right directions.

PAPPA, E. "Me dás letras em vez de dinheiro?" Transações comerciais no Oriente Próximo e no Mediterrâneo Ocidental por volta de 1100-600 a.C.: inovação social e inibição institucional do comércio fenício. R. Museu Arq. Etn., 28: 1-30, 2017.

Resumo: Dois dos problemas mais importantes e fundamentais na pesquisa proto-histórica e antropológica são relacionados à popularização da alfabetização e às origens do dinheiro. As razões por trás da propagação repentina e abrangente do alfabeto fenício no século VIII-VII a.C. permanecem sem solução, apesar dos debates contínuos. Ao mesmo tempo, permanece largamente ignorado na pesquisa acadêmica o paradoxo de que os fenícios, comerciantes da antiguidade por excelência, aparentemente não usaram nenhuma forma de moeda física, apesar de possuírem redes comerciais no Mediterrâneo. No entanto, pesquisas recentes suportam o alto grau de monetização das redes comerciais fenícias, bem como o fato de que formas de "protomoeda" circulavam no Levante pelo menos a partir do século VIII a.C. Este artigo pretende analisar esses dois problemas de uma perspectiva totalmente nova, explorando os vínculos entre eles e testando se uma causalidade pode ser estabelecida entre a repentina divulgação da alfabetização e a ausência de moeda física na economia fenícia, com foco no Ocidente. É sugerido que o aumento da monetização foi possível através dos padrões de intercâmbio comercial estabelecidos no Próximo Oriente desde o terceiro milênio a.C., que permitiram transações usando letras de crédito (notas promissórias), com pagamentos eventuais efetuados em vários meios através de um índice estabelecido de valor (por exemplo, relativo à prata).

Palavras-chave: Monetização; Alfabetização; Alfabeto; Fenícios; Mediterrâneo Ocidental. 


\section{Bibliographic references}

Abulafia, D.T. 2011. The Great Sea: a human history of the Mediterranean. Oxford University Press, Oxford.

Alberti, M.E.; Ascalone, E.; Peyronel, L. 2006. Weights in context. Current approaches to the study of ancient weight systems. In: Alberti, M.E.; Ascalone, E.; Peyronel E. (Eds.) Weights in context. Bronze Age weighing systems of Eastern Mediterranean. Chronology, typology, material and archaeological contexts: proceedings of the International Colloquium Roma 22nd-24th November 2004. Istituto Italiano di Numismatica, Rome, 1-8.

Amadasi-Guzzo, M.G. 1992. Notes sur les graffitis de Mogador. In: Lixus, Actes du colloque organise par l' Institut national de sciencesde l' archéologie et du Patrimoine avec le concours de l' Ecole française de Rome, nov. 1989. École Française de Rome, Rome, 155-157.

Amadasi-Guzzo, M.G., Zamora, J.Á. 2008. Un ostracon phénicien de Tavira (Portugal). Vicino Oriente 14: 231-240.

Amadasi-Guzzo, M.G.; Karageorghis, V. 1977. Fouilles de Kition, III Inscriptions phéniciennes. Department of Antiquities, Nicosia.

Arévalo González, A. 2011. Dinero y moneda en Gadir. In: García-Bellido, M.P.; Callegarin L.; Jiménez Díez A. (Eds.). Barter, money and coinage in the Ancient Mediterranean (10th-1st centuries $B C)$. Consejo Superior de Investigaciones Científicas, Madrid, 227-242.

Aubet, M.E. 2008. Political and economic implications of the new Phoenician chronologies. In: Sagona, C. (Ed.). Beyond the homeland: markers in Phoenician chronology. Peeters, Leuven, 247-260.

Baker, H.D. 2003. Record-keeping practices as revealed by the Neo-Babylonian private archival documents. In: Brosius, M. (Ed.). Ancient archives and archival traditions. Concepts of the recordkepping in the Ancient World. Oxford University Press, Oxford, 241-263.
Balmuth, M.S. 1975. The critical moment: the transition from currency to coinage in the eastern Mediterranean. World Archaeology 6: 293-298.

Belén Deamos, M. 2009. Phoenicians in Tartessos. In: Dietler, M.; López-Ruiz, C. (Eds.). Colonial encounters in Ancient Iberia. The University of Chicago Press, Chicago, 193-228.

Boertien, J.H. 2007. Asherah and Textiles. Biblische Notizen; Aktuelle Beiträge zur Exegese der Bibel und ihrer Welt. Neue Folge 134: 63-77.

Breniquet, C. 2013. Functions and uses of textles in the Ancient near East. Summary and perspectives. In: Nosch, M.L.; Koefoed, H.; Andersson Strand, E. (Eds.). Textile production and consumption in the Ancient near East. Archaeology, epigraphy, iconography. Oxbow Books, Oxford, 1-25.

Brosius, M. 2003. Ancient archives and concepts of record-keeping: an introduction. In: Brosius, $\mathrm{M}$. (Ed.). Ancient archives and archival traditions. Concepts of the record-kepping in the Ancient World. Oxford University Press, Oxford, 1-16.

Campo, M. 2011. Mercado, dinero y moneda en el nordeste de Iberia (ss. V-III a.C.). In: García-Bellido, M.P.; Callegarin, L.; Jiménez Díez, A. (Eds.). Barter, money and coinage in the Ancient Mediterranean (10th-1st centuries BC). Consejo Superior de Investigaciones Científicas, Madrid, 189-202.

Cannavò, A. 2007. The role of Cyprus in the NeoAssyrian economic system: analysis of the textual evidence. Rivista di Fenici 35: 179-190.

Charpin, D. 2010. Reading and writing in Babylon. Harvard University Press, Cambridge, MA.

Chaves Tristán, F. 2011. Trueque, dinero y moneda en la oretania: nuevos documentos. In: GarcíaBellido, M.P.; Callegarin, L.; Jiménez Díez, A. (Eds.). Barter, money and coinage in the Ancient Mediterranean (10th-1st centuries BC). Consejo Superior de Investigaciones Científicas, Madrid, 243-246. 
"You give me letters instead of money?" Commercial transactions in the Near East and the Western Mediterranean ca. 1100-600 BCE: social innovation and institutional inhibition of Phoenician commerce.

R. Museu Arq. Etn., 28: 1-30, 2017.

Chevillon, J-A. 2011. Emporion: un groupe inédit à la tête de dionysos/emporion. In: García-Bellido, M.P.; Callegarin, L.; Jiménez Díez, A. (Eds.). Barter, money and coinage in the Ancient Mediterranean (10th-1st centuries BC). Consejo Superior de Investigaciones Científicas, Madrid, 185-188.

Cunchillos J.L.; Siabra J.; Zamora López J.Á. 2000. Melqart. Sistema gestor de datos fenicios y púnicos / Management system for Phoenician and Punic inscriptions. Ediciones Española e Inglesa, Madrid. (CD-ROM).

Dercksner, J.D. 1999. Trade and finance in Ancient Mesopotamia. Nederlands Instituut voor het Nabije Oosten, Leiden.

Domínguez Arranz, A. 2011. Protomoneda y tesaurización en la fachada tirrénica de italia central (s. XI-VI A.C.). In: García-Bellido M.P.; Callegarin L.; Jiménez Díez A. (Eds.). Barter, money and coinage in the Ancient Mediterranean (10th-1st centuries BC). Consejo Superior de Investigaciones Científicas, Madrid, 85-110.

Domínguez Monedero, A.J. 2011. Circulación de dinero y moneda en la grecia arcaica: el ejemplo de los santuarios. In: García-Bellido, M.P.; Callegarin, L.; Jiménez Díez, A. (Eds.). Barter, money and coinage in the Ancient Mediterranean (10th-1st centuries BC). Consejo Superior de Investigaciones Científicas; Instituto de Historia; Archivo Español de Arqveología; 2011, Madrid, 43-64. Anejos del Archivo Español de Arqueología 58.

Dupont-Sommer, A. 1970. Une inscription phénicienne archaïque récemment trouvée à Kition (Chypre). In: Mémoires de l' Institut National de France 44 (2) C. Klincksieck, Paris, 273-294.

Ferrara, S. 2012. Cypro-Minoan scripts - Analysis. Oxford University Press, Oxford.

Florenzano, M.B.B. 2004. A moeda na Grécia arcaica e clássica - séculos VII a IV a.C.: arqueologia e mudança cultural. Revista do Museu de Arqueologia e Etnologia 14: 67-83.
Frankenstein, S. 1979. The Phoenicians in the Far West: a function of Neo-Assyrian imperialism. In: Larsen, M.T. (Ed.). Power and propaganda: a symposium on Ancient Empire. Akademisk, Copenhagen, 263-294.

García-Bellido, M.P. 2011. Hackgold and Hacksilber in protomonetary Iberia. In: García-Bellido, M.P.; Callegarin, L.; Jiménez Díez, A. (Eds.). Barter, money and coinage in the Ancient Mediterranean (10th-1st centuries BC). Consejo Superior de Investigaciones Científicas; Instituto de Historia; Archivo Español de Arqveología, Madrid, 121-138. Anejos del Archivo Español de Arqueología 58.

Gitin, S.; Golani, A. 2001. The Tel Miqne-Ekron silver hoards: the Assyrian and Phoenician connections. In: Balmuth, M.S. (Ed.). Hacksilber to coinage: new insights into the monetary history of the Near East and Greece. American Numismatic Society, New York, 32-33, 38.

Gitin, S.; Golani, A. 2004. A silver-based monetary economy in the seventh century BCE: a response to Raz Kletter. Levant 36: 203-205.

Goldwasser, O. 2011. The advantage of cultural periphery: the invention of the alphabet in Sinai (circa 1840 B.C.E). In: Sela-Sheffy, R.; Toury, G. (Eds.). Culture contacts and the making of cultures: papers in homage to Itamar Even-Zohar. Tel Aviv University, Tel Aviv, 251-316.

Gomes, F.B. 2012. Aspectos do sagrado na colonização fenícia. Centro de Arquelogia da Universidade de Lisboa, Lisboa.

González de Canales Cerisola, F.; Serrano Pichardo, L.; Llompart Gómez, J. 2006. The Pre-colonial Phoenician Emporium of Huelva (ca. 900-770 BC). Bulletin Antieke Beschaving 81:13-29.

Grottanelli, C. 1988. Of gods and metals. On the economy of Phoenician sanctuaries. Scienze dell' Antichità 2: 243-255.

Gubel, E. 2006. Notes of the Phoenician component of the Orientalising horizon. In: Riva, C.; Vella, N. 
(Eds). Debating orientalisation: multidisciplinary approaches to change in the Ancient Mediterranean. Equinox, London, 85-93.

Hart, K.; Ortiz H. 2014. The anthropology of money and finance: between ethnography and world history. Annual Review of Anthropology 43: 465-482.

Healey, J.P. 1974. The Kition tariffs and the Phoenician cursive series. Bulletin of the American Schools of Oriental Research 216: 53-60.

Jursa, M. 2010. Aspects of the economic history of Babylonia in the First Millennium BC. Economic geography, economic mentalities, agriculture, the use of money and the problem of economic growth. Ugarit-Verlag, Münster.

Jursa, M. 2015. Market performance and market integration in Babylonia in the "long sixth century” BC. In: van der Spek, R.J.; van Leeuwen, B.; van Zanden, J.L. (Eds). A history of market performance. From Ancient Babylonia to the modern world. Routledge, London; New York, 83-106.

Karageorghis, V. 2005. Excavations at Kition V: the Phoenician and Later levels. Part I. With a Contribution by Oliver Callot. Department of Antiquities, Nicosia.

Katsari, C. 2010. The monetization of Rome's frontier provinces. 2. ed. In: Harris, W.V. (Ed.). The monetary systems of the Greeks and Romans. Oxford University Press, Oxford, 242-267.

Kim, H. 2001. Archaic coinage as evidence for the use of money. In: Meadows, A.; Shipton, K. (Eds.). Money and its uses in the ancient Greek world. Oxford University Press, Oxford, 7-21.

Kleber, K. 2016. The Kassite gold and the PostKassite silver standards revisited. In: Kleber, K.; Pirngrüber, R. (Eds.). Silver, money and credit. A tribute to Robartus J. van der Spek on occasion of his 65th birthday on 18th September 2014. The Netherlands Institute for the Near East, Leiden, 37-55.
Kletter, R. 2003. Iron age hoards of precious metals in Palestine - an "underground economy"? Levant 35: 139-152.

Kletter, R. 2004. Coinage before coins? A response. Levant 36: 207-210.

Kormikiari, M.C.N. 2004. O comércio, as trocas e o sistema do dom entre os fenícios. In: Carvalho, A.G. (Ed.). Interação social, reciprocidade e profetismo no mundo antigo. UESB, Vitória da Conquista, 127-154.

Kroll, J.H. 2011. Money of the Greeks and their Near Eastern neighbors before the advent of coinage, and after. In: García-Bellido, M.P.; Callegarin, L.; Jiménez Díez, A. (Eds). Barter, money and coinage in the Ancient Mediterranean (10th-1st centuries BC). Consejo Superior de Investigaciones Científicas, Madrid, 15-24.

Lemaire, A. 2008. The spread of alphabetic scripts (c. 1700-500 BCE). Diogenes 55: 45-58.

López Ruiz, U.; Ruiz Tinoco, A.M. 2011. Adopción y uso de la moneda en el Suroeste Peninsular a través de la circulación monetaria. In: García-Bellido, M.P.; Callegarin, L.; Jiménez Díez, A. (Eds.) Barter, money and coinage in the Ancient Mediterranean (10th-1st centuries BC). Consejo Superior de Investigaciones Científicas, Madrid, 267-288.

Mayet, F.; Silva, C.T.; 2000. Le site phénicien d'Abul (Portugal): comptoir et sanctuaire. De Boccard, Paris.

Marín Ceballos, M.C.; Jiménez Flores, A.M. 2004. Los santuarios fenicio-púnicos como centros de sabiduría: el Templo de Melkart en Gadir. Huelva Arqueológica 20: 215-240.

Marzoli, D.; El Khayari, A. 2009. Mogador (Essaouira, Marokko) - Vorbericht über die Kampagnen 2006 und 2007, mit einem Beitrag von. H. Brückner und J. Lucas, mit 15 Abbildungen, Farbtafel 2 und den Tafeln 1-3. Madrider Mitteilungen 50: 80-117.

Marzoli, D.; El Khayari, A. 2010. Vorbericht Mogador (Marokko) 2008, mit Beiträgen von. F. Arnold, St. 
"You give me letters instead of money?" Commercial transactions in the Near East and the Western Mediterranean ca. 1100-600 BCE: social innovation and institutional inhibition of Phoenician commerce.

R. Museu Arq. Etn., 28: 1-30, 2017.

Arnold, C. Becker, H. C. Küchelmann, R. Neef, H. Brückner und J. Lucas, mit 29 Textabbildungen. Madrider Mitteilungen 51: 61-108.

Master, D.M. 2003. Trade and politics: Ashkelon's balancing act in the seventh century B.C.E. Bulletin of the American Schools of Oriental Research 330: 47-64.

Mederos, A.; Lamberg-Karlovsky, C.C. 2004. Weight systems and trade networks in the Old World (2500 - 1000 BC). In: Hudson, M.; Wunsch, C. (Eds.). Creating economic order. Record-keeping, standardization and the development of accounting in the ancient Near East: a colloquium held at the British Museum November 2000. CDL Press, Bethesda, 121-214.

Michailidou, A. 2001. Script and metrology: practical processes and cognitive inventions. In: Michailidou, A. (Ed.). Manufacture and measurement: counting, measuring and recordingcraft items in early Aegean societes. Research Centre for the Greek and Roman Antiquity; National Hellenic Research Foundation, Athens, 53-82.

Michailidou, A. 2005. Weight and value in pre-coinage societies: an introduction. Research Centre for the Greek and Roman Antiquity, National Hellenic Research Foundation, Athens.

Montero Ruiz, I.; Pérez, A.; Rafel, N. 2011. Sobre la procedencia de los metales de las primeras monedas del ne ibérico. Aplicación de análisis de isótopos de plomo. In: García-Bellido, M.P.; Callegarin, L.; Jiménez Díez, A. (Eds.). Barter, money and coinage in the Ancient Mediterranean (10th-1st centuries BC). Consejo Superior de Investigaciones Científicas, Madrid, 203-212.

Mora Serrano, B. 2011. Ponderales, moneda y mercado en la málaga tardopúnica: la primera monetización de malaca y su territorio. In: García-Bellido, M.P.; Callegarin, L.; Jiménez Díez, A. (Eds.). Barter, money and coinage in the Ancient Mediterranean (10th-1st centuries BC). Consejo Superior de Investigaciones Científicas, Madrid, 169-184.
Moore, K.; Reid, S. 2008. The birth of brand: 4000 years of branding. Business History 50: 419-432.

Pappa, E. 2013. Early Iron Age exchange in the West: phoenicians in the Mediterranean and the Atlantic. Leuven, Paris; Walpole.

Pappa, E. 2015a. Oriental gods but domestic elites? Religious symbolism and economic functions of Phoenician-period cult loci in south Iberia. In: Kistler, E.; Öhlinger B.; Mohr M. (Eds.) Sanctuaries and the power of consumption. Networking and the formation of elites in the archaic Western Mediterranean World. Proceedings of the International Conference Innsbruck, 20th-23rd March 2012. Harrassowitz Verlag, Wiesbaden, 43-62.

Pappa, E. 2015b. The Phoenician sanctuary of Palácio de Galeria in Tavira (Portugal): overview, selected contexts and their assemblages from the excavations of the Campo Arqueológico de Tavira. Bellaterra, Barcelona.

Pappa, E. 2015c. Who's the Phoenician on the Atlantic? Disentangling seafaring from colonisation in western Iberia and Morocco". In: Pedersen, R.; Held, W. (Ed.). On sea and ocean: new research in Phoenician seafaring, 23-25 June 2011, Archäologisches Seminar. Philipps Universität Marburg, Marburg, 71-94.

Peyronel, L. 2010. Ancient Near Eastern economics. The silver question between methodology and archaeological data. In: Matthiae, P. et al. (Eds.). Near Eastern Archaeology in the past, present and future. Heritage and identity. Ethnoarchaeological and interdisciplinary approach, results and perspectives. Visual expression and craft production in the definition of social relations and status. Harrassowitz Verlag, Wiesbaden, 925-948.

Powell, B.B. 1991. Homer and the origin of the Greek alphabet. Cambridge University Press, Cambridge.

Radner, K. 1999. Money in the Neo-Assyrian Empire. In: Dercksen, J.D. (Ed.). Trade and finance in ancient Mesopotamia. Nederlands Instituut voor het Nabije Ooosten, Istanbul, 127-156. 
Ripollès, P.P. 2011. Cuando la plata se convierte en moneda: Iberia Oriental. In: García-Bellido, M.P.; Callegarin, L.; Jiménez Díez, A. (Eds.). Barter, money and coinage in the Ancient Mediterranean (10th-1st centuries BC). Consejo Superior de Investigaciones Científicas, Madrid, 213-226.

Rodríguez Casanova, I. 2011. Alteraciones en moneda hispánica: algunas reflexiones sobre la moneda cizallada. In: García-Bellido, M.P.; Callegarin, L.; Jiménez Díez, A. (Eds). Barter, money and coinage in the Ancient Mediterranean (10th-1st centuries $B C)$. Consejo Superior de Investigaciones Científicas, Madrid, 247-266.

Ruiz de Arbulo, J. 2000. El papel de los santuarios en la colonización fenicia y griega en la Península Ibérica. In: Costa, B.; Fernández, J.H. (Eds.). Santuarios fenicio-punicos en Iberia y su influencia en los cultos indígenas (XIV Jornadas de Arqueología Fenicio-Púnica). Museu Arqueològic d'Eivissa i Formentera, Ibiza, 9-56.

Ruiz-Gálvez Priego, M. 2008. Writing, counting, selfawareness, experiencing distant worlds. Identity processes and freelance trade in the Bronze Age/ Iron Age transition. In: Celestino Pérez, S.; Ráfels, S.N.; Armada, X. (Eds). Contacto cultural entre el Mediterráneo y el Atlántico (siglos XII-VIII ane). La precolonización a debate. CSIC Escuela Española de Historia y Arqueología en Roma, Roma, 27-40.

Ruiz-Gálvez, M. 2014. Atlantic Iberia: a threshold between East and West. In: Almagro-Gorbea, M. (Ed.). Iberia. Protohistory of the Far West of Europe: from Neolithic to Roman conquest. Universidad de Burgos, Burgos, 161-180.

Salete da Ponte, M. 2001. Corpus Signorum das fibulas proto-historicas e romanas de Portugal. Dissertação de Doutoramento. Universidade do Porto, Porto.

Sanders, S.L. 2004. What was the alphabet for? The rise of written vernaculars and the making of Israelite national literature. MAARAV 11: 25-56.

Schaps, D.M. 2004. The invention of coinage and the monetization of Ancient Greece. The University of Michigan Press, Ann Arbor.
Scheidel, W. 2010. The divergent evolution of coinage in eastern and western Eurasia. In: Harris, W.V. (Ed.). The monetary systems of the Greeks and Romans. 2. ed. Oxford University Press, Oxford, 267-286.

Shea, W.H. 2012. The inscribed tablets from tell Deir Alla. Andrews University Seminary Studies 27: 21-37.

Sherratt, S.; Sherratt, A. 1993. The growth of the Mediterranean economy in the early first millennium BC. World Archaeology 24: 361-378.

Sommer, M. 2007. Networks of commerce and knowledge in the Iron Age: the case of the Phoenicians. Mediterranean Historical Review 22: 97-111

Stockhammer, P. 2016. Past food for thought. The potential of archaeology. Gastronomika 16: 91-101.

Thompson, C.M. 2003. Sealed silver in Iron Age Cisjordan and the invention of coinage. Oxford Journal of Archaeology 22: 67-103.

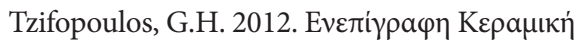

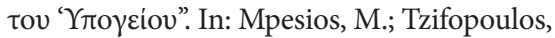

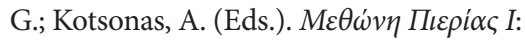

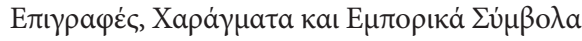

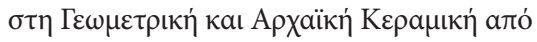

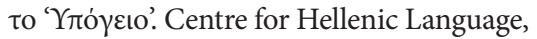
Thessaloniki, 315-320.

Van der, R.J.; van Leeuwen, B.; van Zanden, J.L. (Eds.). 2015. A history of market performance from Ancient Babylonia to the modern world. Routledge, London.

Valério, M. 2008. Origin and development of the Palaeohispanic scripts: the orthography and phonology of the Southwestern alphabet. Revista Portuguesa de Arqueología 11: 107-138.

Valério, M. 2016. Reflexões sobre a origem e formação da escrita paleo-hispânica do sudoeste e o seu lugar na história dos sistemas de escrita. Palaeohispánica 16: 115-151. 
"You give me letters instead of money?" Commercial transactions in the Near East and the Western Mediterranean ca. 1100-600 BCE: social innovation and institutional inhibition of Phoenician commerce.

R. Museu Arq. Etn., 28: 1-30, 2017.

Vila Franco, M.I. 2011. El proceso de monetización del noroeste de la península ibérica: las calzadas romanas. In: García-Bellido, M.P.; Callegarin, L.; Jiménez Díez, A. (Eds.). Barter, money and coinage in the Ancient Mediterranean (10th-1st centuries BC). Consejo Superior de Investigaciones Científicas, Madrid, 369-376.

Vilaça, R. 2011. Ponderais do Bronze Final-Ferro Inicial do Ocidente Peninsular: novos dados e questões em aberto. In: García-Bellido, M.P.; Callegarin, L.; Jiménez Díez, A. (Eds.). Barter, money and coinage in the Ancient Mediterranean (10th-1st centuries BC). Consejo Superior de Investigaciones Científicas, Madrid, 139-167.

Vilaça, R. 2013. Late Bronze Age Mediterranean impacts in the western end of the Iberian Peninsula (actions and reactions). In: Aubet, M.E.; Sureda, P. (Eds.). Interacción social y comercio en la Antesala del Colonialismo. Bellaterra, Barcelona, 13-41.
Vives-Ferrándiz Sánchez, J. 2005. Negociando encuentros: situaciones coloniales e intercambios en la costa oriental de la Península Ibérica (ss. VIIIVI a.C.). Bellaterra, Barcelona.

Xella, P.; Zamora López, J.Á. 2007. The Phoenician Data Bank. The international project Corpus Inscriptionum Phoenicarum necnon Punicarum. In: Dietrich, M.; Loretz, O. (Eds.). UgaritForshungen. Internationales Jahrbuck für die Altertumkunde Syrien-Palästinas 39. Ugarit Verlag, Münster, 773-790.

Zamora López, J.Á. 2005. La práctica de escribir entre los primeros fenicios peninsulares y la introducción de la escritura entre los pueblos paleohispánicos. Palaeohispánica 5: 155-192.

Zamora López, J.Á. in press. Phoenician epigraphy. In: Sinner, A.G.; Velaza, J. (Eds.). Palaeohispanic Languages and Epigraphies 26. Oxford University Press, Oxford. 